\title{
EFEITOS DOS TRATAMENTOS FÍSICO, FISICO-QUÍMICO E TEMPO DE ARMAZENAMENTO SOBRE A COMPOSIÇÃO DA FRAÇÃO NITROGENADA DA LEVEDURA LIQUIDA (Sacharomyoes spp.) DE DESTILARIAS DE ÁLCOOL
}

\author{
ANTÓNIO FERNANDO BERGAMASCHINE \\ Zootecnista
}

Orientador: Prof. Dr. WILSON ROBERTO S. MATTOS

Dissertação apresentada à Escola Superior de Agricultura "Luiz de Queiroz", da Universidade de São Paulo, para obtenção do título de Mestre em Agronomia - Área de Concentração: Nutrição Animal $\theta$ Pastagens.

$P|R A C| C A B A$

Estado de São Paulo - Brasil

Abril - 1986 
Ao meu pai

À minha mãe

(in memorian)

Aos meus irmãos

cunhados, sobrinhos

e sogros,

DEDICO .

A minha esposa Irene

e aos meus filhos Alex

e Aline,

OFEREÇO . 


\section{AGRADEC IMENTOS}

Ao Professor Dr. Wilson Roberto Soares Mattos, pela orientação e apoio.

Aos Professores Dr. Raul Dantas d'Arce e Dr. Paulo Fernando Machado, pela cooperação.

Ao Professor Dr. Luiz Eduarảo Guitierrez, pelas valiosas sugestões.

À Técnica de Laboratório Ana Maria Zani de Moura e ao Auxiliar de Laboratório Sr. José Seghesi, pela amizade.

Ao Departamento de Zootecnia da ESALQ - USP, SP, por ter permitido a realização deste trabalho.

À Universidade Estadual Paulista "Júlio de Mes quita Filho", por ter possibilitado a realização do curso de Pós-Graduação .

Ao PICD/CAPES, pela concessão da bolsa de estu do.

A Companhia Agrícola Santa Bárbara (Usina Santa Bárbara - S.P.), pela doaşão da levedura. 
E a todos que direta ou indiretamente contribui ram para realização deste trabalho. 


\section{INDICE}

Página

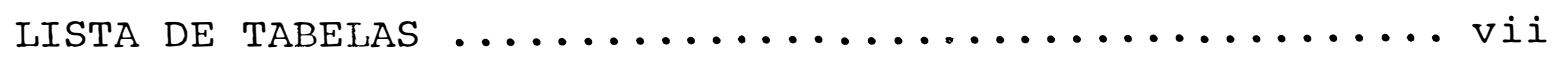

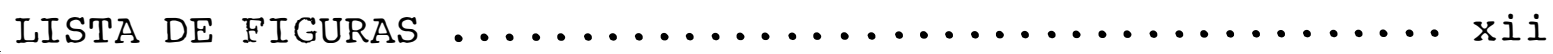

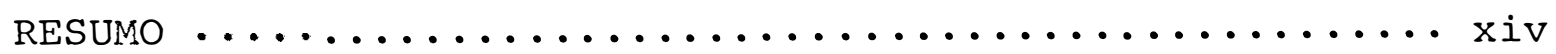

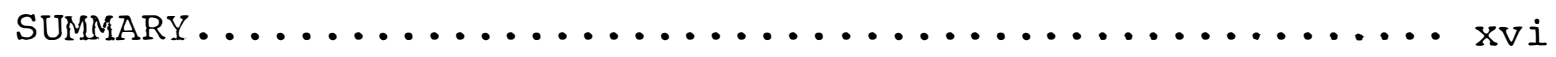

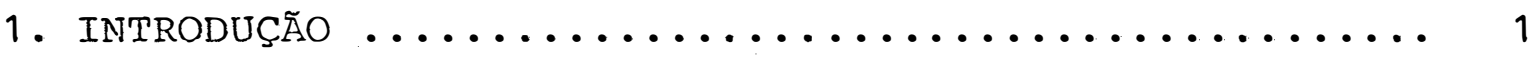

2. REVISÃo dE LITERATURA ............................ 3

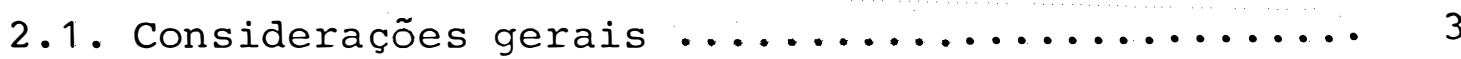

2.2. Tipos de levedura e sua obtenção ............. 4

2.3. Valor nutritivo das leveduras .............. 5

2.3 .1$. Composição quimica................. 5

2.3.2. Uso na alimentação....................... 11

2.3.3. Efeito tóxico.................... 14

2.4. Processos àe conservação das leveảuras......... 15

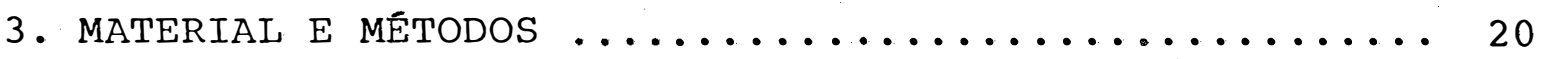

4. RESUltados E DiscUSSÃo ........................ 24

4.1. Composição da levedura utilizada ............ 24

4.2. Teores de matéria seca ................... 28

4.3. Teores de nitrogênio total .............. 34

4.4. Teores de nitrogênio solúvel .............. 40

4.5. Teores de nitrogênio amoniacal ............ 48

4.6. Teores de nitrogênio não protéico .......... 52

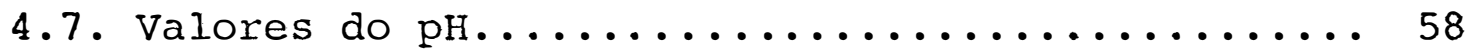

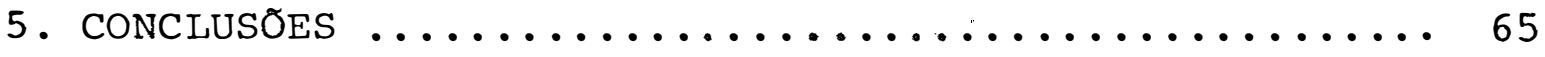


6. IITERATURA CITADA ............................ 66

7. APENDICES ...................................... 67 


\section{LISTA DE TABELAS}

1 Composição química de vários tipos de leve

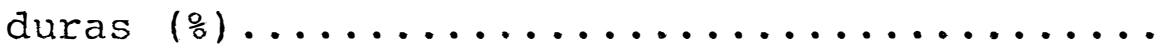

2 Composição em aminoácidos de várias levedu ras em comparação com o farelo de soja....... 9

3 Composição bromatológica da levedura (médi as de duas determinações).................. 25

4 Composição em aminoácidos da levedura....... 26

5 Composição em minerais da levedura......... 27

6 Teores da matéria seca $\left(105^{\circ} \mathrm{C}\right)$ da levedura líquida em função dos tratamentos $(T)$ e dos tempos de armazenamento $\left(T_{a}\right)$ em dias (mé

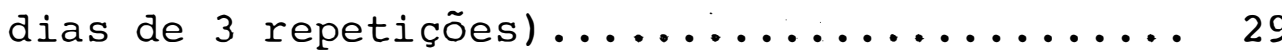

7 Análise de variância para os teores da ma tēria seca da levedura líquida em função dos tratamentos (T) e dos tempos de armaze

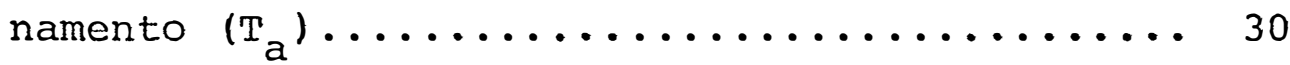

8 Equações de regressão, pontos de máximo,mí nimo e de inflexão e, coeficientes de de terminação $\left(R^{2}\right)$, dos teores da matéria se 
ca (Y) da levedura líquida, em função dos tempos de armazenamento (x), submetia a diferentes tratamentos $(\mathrm{T}) \ldots \ldots \ldots \ldots . \ldots . \ldots 32$

9 Teores de nitrogênio total (NT) da levedu ra líquida em função dos tratamentos (T) e dos tempos de armazenamento $\left(\mathrm{T}_{\mathrm{a}}\right)$ em dias (média de 3 repetições) ................. 35

10 Análise de variância para os teores de ni trogênio total da levedura liquida em fun ção dos tratamentos (T) e dos tempos de aㅗ mazenamento $\left(\mathrm{T}_{\mathrm{a}}\right) \ldots \ldots \ldots \ldots \ldots \ldots \ldots \ldots \ldots \ldots$

11 Equações de regressão, pontos de máximo,mí nimo e de inflexão e, coeficiente de deter minação $\left(R^{2}\right)$, dos teores de nitrogênio to tal (Y) da levedura líquida, em função dos tempos de armazenamento $(\mathrm{x})$, submetida a diferentes tratamentos $(\mathrm{T}) \ldots \ldots \ldots \ldots \ldots \ldots$

12 Teores de nitrogênio solúvel (NS) da leve dura líquida em função dos tratamentos (T) e dos tempos de armazenamento $\left(\mathrm{T}_{\mathrm{a}}\right)$ em dias

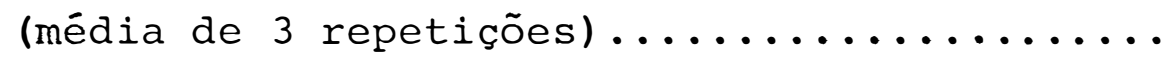


Análise de variância para os teores de ni trogênio solúvel da levedura líquida em fun ção dos tratamentos (T) e dos tempos de ar

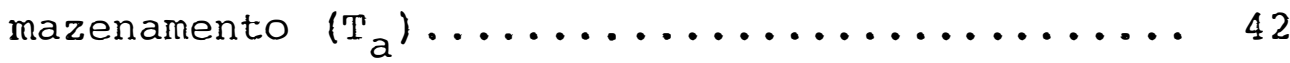

14 Equações de regressão, pontos de máximo,mí nimo e de ịnflexão e, coeficientes dedeter minação $\left(\mathrm{R}^{2}\right)$, dos teores de nitrogênio so lúvel (Y) da levedura líquida, em função dos tempos de armazenamento (x), submetida a diferentes tratamentos (T)............. 43

15 Teores de nitrogênio amoniacal (NA) da le vedura líquida em função dos tratamentos (T) e dos tempos de armazenamento $\left(\mathrm{T}_{\mathrm{a}}\right)$ em

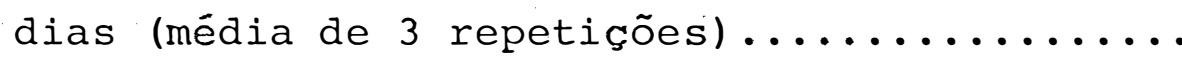

16 Análise de variância para os teores de ni trogênio amoniacal da levedura líquida em função dos tratamentos (T) e dos tempos de armazenamento $\left(\mathrm{T}_{\mathrm{a}}\right) \ldots \ldots \ldots \ldots \ldots \ldots \ldots \ldots . \ldots \ldots$

17 Equações de regressão, pontos de máximo,mí nimo e de inflexão e, coeficientes de deter minação $\left(R^{2}\right)$, dos teores de nitrogênio amo niacal (Y) da levedura líquida, em função 
dos tempos de armazenamento (x), submetida a diferentes tratamentos $(\mathrm{T}) \ldots \ldots \ldots \ldots \ldots \ldots$

Teores de nitrogênio não protéico (NNP) da levedura líquida em função dos tratamentos (T) e dos tempos de armazenamentos ( $\mathrm{Ta}$ ) em dias (média de 3 repetições)............. 53

19 Análise de variância para os teores de ni trogênio não protéico da levedura líquida em função dos tratamentos (T) e dos tempos de armazenamento $\left(\mathrm{T}_{\mathrm{a}}\right) \ldots \ldots \ldots \ldots \ldots \ldots \ldots \ldots$

20 Equações de regressão, pontos de máximo,mí nimo e de inflexão e, coeficiente de deter minação $\left(R^{2}\right)$, dos teores de nitrogênio não protéico (Y) da levedura líquida,em função dos tempos de armazenamento (x), submetida a diferentes tratamentos $(\mathrm{T}) \ldots \ldots \ldots . . \ldots . \ldots 56$

21 Valores de $\mathrm{pH}$ da levedura líquida em função dos tratamentos (T) e dos tempos de armaze namento $\left(\mathrm{T}_{\mathrm{a}}\right)$ em dias (média de 3 repeti

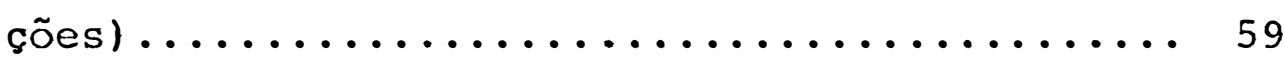


Tabela

22 Análise de variância para os valores de $\mathrm{pH}$ da levedura líquida em função dos tratamen tos (T) e dos tempos de armazenamento

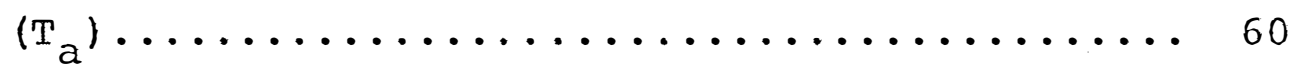

23 Equações de regressão, pontos de máximo,mî nimo e de inflexão e, coeficientes de deter minação $\left(\mathrm{R}^{2}\right)$, dos valores de $\mathrm{pH}$ da levedu ra liquida (Y), em função dos tempos de ar. mazenamento $(x)$, submetida a diferentes tra

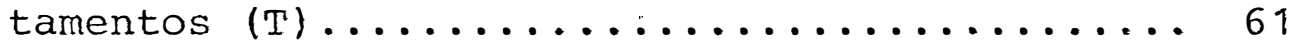




\section{LISTA DE FIGURAS}

Figura

Página

1

Esquema do processo de produção de açucar e álcool e da recuperação da levedura ....... 21

2 Curvas, equações de regressao e coeficientes de determinação $\left(R^{2}\right)$ dos teores de matéria seca da levedura (Y) em função do tempo de armazenamento $(\mathrm{x})$, submetida a diferentes tratamentos $(\mathrm{T})$.

3 Curvas, equação de regressão e coeficien tes de determinação $\left(R^{2}\right)$ dos teores de $n \underline{i}$ trogênio total da levedura $(x)$, submetida

a diferentes tratamentos (T)................ 39

4 Curva, equação de regressão e coeficien tes de determinação $\left(R^{2}\right)$ dos teores de $n \underline{i}$ trogênio solúvel da levedura (Y) em função do tempo de armazenamento $(x)$, submetida a diferentes tratamentos (T) .............. 44

5 Curvas, equações de regressão e coeficien tes de determinação $\left(R^{2}\right)$ dos teores de $n \underline{i}$ trogênio amoniacal da levedura (Y) em fun 
ção do tempo de armazenamento (x), submeti da a diferentes tratamentos (T) ........... 45

6 Curvas, equação de regressão e coeficientes de determinação $\left(\mathrm{R}^{2}\right)$ dos teores de nitrogê nio não protéico da levedura (Y) em função dos tempos de armazenamento $(x)$, submetida a diferentes tratamentos $(T) \ldots \ldots \ldots \ldots \ldots$

7 Curvas, equações de regressão e coeficien tes de determinação $\left(\mathrm{R}^{2}\right)$ dos valores de $\mathrm{pH}$ da levedura (Y) em função dos tempos de ar mazenamento. $(x)$, submetida a diferentes tra

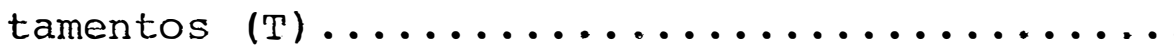




\author{
EFEITOS DOS TRATAMENTOS FISICO, FISICO-QUIMICO E \\ TEMPO “ DE ARMAZENAMENTO SOBRE A COMPOSIC̣ÃO DA FRAÇĀO \\ NITROGENADA DA LEVEDURA LIQUIDA (Saccharomyces spp) \\ DE DESTILARIAS DE ÁLCOOL
}

AUTOR: ANTONIO FERNANDO BERGAMASCHINE

ORIEITTADOR: PROF. DR. WILSON ROBERTO S. MATTOS

\title{
RESUMO
}

A pesquisa foi desenvolvida no Departamento de Zootecnia da ESALQ - USP, em Piracicaba - SP.

O objetivo foi estudar a influência dos tratamen tos fisico (vapor), físico-químico (vapor e amônia) e tempo de armazenamento na composição da fração nitrogenada da levedu ra líquida de destilaria de álcool.

O delineamento experimental foi em blocos casualizados com parcelas subdivididas, consiảerando como parcelas os tratamentos, e os tempos de armazenamento, como subparcelas. Os tratamentos foram: $\mathrm{T}_{1}$ - Testemunha; $\mathrm{T}_{2}-$ vapor + anaerobiose; $\mathrm{T}_{3}$ vapor $+0,3 \%$ de amônia; $\mathrm{T}_{4}$ - vapor $+0,6 \%$ de amõnia; $\mathrm{T}_{5}$-vapor. Os tempos de armazenamento que coincidiram com as épocas de a- 
mostragem foram $0,7,14,21$ e 28 dias. Analisaram-se os seguintes parâmetros: matéria seca, nitrogênio total, nitrogênio so lúvel, nitrogênio amoniacal e nitrogênio não protéico.

Concluiu-se que:

O teor de matéria seca da levedura liquida teve um ligeiro acréscimo; durante os 28 dias de armazenamento, exce to o tratamento dois.

No tratamento testemuriha, os teores de nitrogênio solúvel, nitrogênio amoniacal e nitrogênio não proteíco, elevaram-se .com o passar do tempo, indicando degradação protéica da levedura.

A condição de anaerobiose não influenciou a conservação da levedura.

A adição de $0,3 \%$ e $0,6 \%$ de amônia aos tratamen tos três e quatro, respectivamente, proporcionou elevações nos seus teores de nitrogênio total, solúvel, amoniacal e não pro téico, que persistiram durante todo o tempo experimental.

A aplicação exclusiva de vapor foi suficiente para conservar a levedura liquida por 30 dias de armazenamento, embora a aplicação conjunta de vapor e amônia e, vapor e anaerobio se também tenhar. sicio eficientes. 


\section{THE EFFECTS OF PHYSICAL, PHYSICO-CHEMICAL AND TIME OF STORAGE TREATMENT IN THE COMPOSITION OF THE NITROGENOUS \\ FRACTION OF LIQUID YEAST (Saccharomyces spp) OF ALCOHOL DESTILLERIS}

Author: ANTOOHIO FERNANDO BERGAMASCHINE

Adviser: DR. WILSON ROBERTO S. MATTOS

\section{SUMMARY}

This reserch was conduced in the Departamento de Zootecnia da ESALQ - USP, Piracicaba - SP.

The purpose of this research was to study the influence of physical (vapor) and physico chemical. ( vapor and ammonia ) treatment and the time of storage in the composition of nitrogenized fraction of liquid yeast of alcohol destillery.

The experimental design was in randomized blocks disposed in split-plots, considering the treatment as plots and the storage time as subplot. The treatments were: $\mathrm{T}_{1}-$ Control; $\mathrm{T}_{2}$ - vapor + anaerobiose; $\quad \mathrm{T}_{3}$ - vapor $+0,3 \%$ of ammonia; $\mathrm{T}_{4}$ - vapor $+0,6 \%$ of ammonia; $\mathrm{T}_{5}$ - vapor; the storage 
times coincident with sampling period were 0, 7, 14, 21 and 28 days. The following parameters were analized: dry matter, total nitrogen, soluble nitrogen, ammoniacal nitrogen and noprotein nitrogen.

Conclusions :

The dry matter of liquid yeast content was lightly increased during the 28 days of storage except in the treatment 2 .

The contents of soluble, ammoniacal and noprotean nitrogen increased with the overtime in control, showing protein degradation of yeast.

The anaerobic condition did not influence the yeast conservation.

The addition of $0,3 \%$ e. $0,6 \%$ of ammonia in treatment 3 and treatment 4 , respectively, increased the contents of soluble, ammoniacal and non-protein nitrogen. The increase persisted for the whole experimental period.

The application of vapor only was sufficient to conserve the liquid yeast by 30 days of storage, although the simultaneous application of vapor + ammonia and vapor + anaero biosis were also efficient. 


\section{INTRODUCAO}

Além de promover a fermentação alcoólica, a le vedura é uma fonte rica de proteínas e vitaminas do complexo B, constituindo-se em uma fonte alternativa de proteinas fren te à elevação dos custos de produção de suplementos protéicos convencionais e ao aumento da demanda desse nutriente indispen sável à dieta animal e humana.

No Brasil, o cultivo de microorganismos destina dos 'a alimentação animal ou humana, ainda não se estabeleceu industrialmente, embora se possa observar a presença da levedu ra seca nas prateleiras dos supermercados e como ingrediente em rações para animais.

Nas dornas de fermentação das destilarias de ál cool, quando termina a fermentação alcoólica, as células de le vedura são separadas do vinho fermentado através de centrifugação para servirem de inóculo em novo mosto, ou para serem enviadas juntą 
tamente com $\circ$ vinho às colunas de destilação. Desse mate rial pode-se separar uma certa quantidade para a produção de proteina unicelular.

De acordo com as metas estabelecidas pelo gover no para produção de álcool no Brasil, nos anos de 1983/84 a 1986/87 (NOGUEIRA,1982), considerando-se a obtenção de $2 \mathrm{Kg}$ de leveaura seca por 100 litros de álcool DESMONTS (1968) e o teor de 18\% de materia seca da levedura, pode-se estimar que a produção anual de levedura líquida nestes anos atingirá 900.000 toneladas, em média, não considerando a levedura restante no final da safra nem aquela prov niente de fundos de dornas.

A desidratação ou a secagem da levedura facilí ta seu armazenamento e sua mistura com outros ingredientes da ração. Porém, é um processo que envolve gasto de energia e in vestimentos em equipamentos de secagem que podem elevar o cus to do produto e conseqüentemente diminuir a viabilidade econô mica de seu uso. No entanto, o amazenamento da levedura "in natura" lcé lulas vivas) pode ocasionar mudanças na sua fração protéica e deterioração, comprometendo seu valor alimentício e tornando-a imprópria como alimento.

o presente trabalho teve como objetivo estudar a influência dos tratamentos físico (vapor), físico-químico (vapor e amô nia) e tempo de armazenamento na composição da fração ní trogenada da levedura líquida de destilarias de álcool. 


\section{REVISAO DE LITERATURA}

\subsection{CONSIDERAÇÕES GERAIS}

Ós fungos, leveduras, bactérias e algumas vezes as algas, são correntemente qualificadas como fontes: de proteí nas novas ou não convencionais. Isto não é totalmente verdade, posto que todas elas são muito antigas e veri sendo utilizadas na alimentação humana desde centenas ou até milhares de anos (SHACKLADY e WALKER, 1973). Em ampla revisão sobre o assunto, LIMA (1966) observou que desde 1756 já se fazia uso dos sedị mentos das dornas de fermentação alcoólica na alimentação ani mal. 


\subsection{TIPOS DE LEVEDURA E SUA OBTENGÄJ}

Basicamente as destilarias de álcool podem prô duzir dois tipos de levedura (DESMONTS, 1966): As leveduras do gênero Saccahromyces, recuperadas dos vinhos da fermentáção alcoólica, por centrifugação, denominadas de "levedura de recuperação" e as leveduras do gênero Candida ou Torula cultivá veis sobre vinhaça, em instalações anexas às destilarias de álcool ou sobre melaço em usinas de açucar, sendo denominadas de "leveduras de cultura". São também cultivadas em resícuos da extração da celulose (IIMA,1966), em soro de leite e resíduos de destilarias de petróleo (DESPOîTS, 1968), e diversos outros substratos, tais como o bagaço de laranja, resíduos do processamento de frutas, raízes e melaços (VANANUVAT, 1977).

As leveduras de recuperação constituem um sub produto da fermentação alcoólica, enquanto que as leveduras de cultura são obtidas nara fins específicos (DESMONTS, 1966). Segundo AMORIN e MATTOS (1982) a recuperação das leveduras no processo da fermentação alcoólica pode ser feita de duas ma neiras: do fundo de dornas e através do desvio do leite de le vedo, que é a levedura concentrada logo após a centrifugação do mosto. De acordo com esses mesmos autores, o material do fun do das dornas contém além de levedura, bagacilho, terra, are ia,sais insolúveis, água e sais minerais. A composição deste 
material depende da maneira como a matéria prima foi processa da, isto é, se o caldo foi aquecido e clarificado, se o mosto é de melaço mais caldo, ou melaço mais água, ou outra combina ção. O uso do melaço e caldos não clarificados pode produzir residuos de dornas mais impuros. A produção de concentrados pro téicos exigirá algumas práticas para melhorar a qualidade, tal como coar o material para depois concentrá-lo e desidratá-lo.

o. material obtido através do desvio de uma parte das leveduras - centrifugadas, é mais pu ro e concentrado, sendo mais apropriado para a alimentação an mal.

Um outro tipo de levedura empregado na alimenta ção animal é a utilizada na fabricação de cerveja, que juntamente com a polpa seca de cervejaria, constituem os subprodutos mais importante dessa indústria (MIYADA, 1978).

\subsection{VALOR NUTRITIVO DAS LEVEDURAS}

\subsubsection{COMPOSI ÇÃO QUIMICA}

As leveduras possuem alto teor de proteína, e quanto ä composição en aminoácidos estão entre as melhores fontes protéicas de origem vegetal, mas não tão boas como as proteí nas de origem animal (ENSMINGER, 1970). A Tabela 1 apresenta vários tipos de leveduras e suas respectivas composições quínicas.

O teor de proteina bruta $(\mathrm{N} \times 6,25)$ é bastante variável (30-60\%), constituindo-se de cerca de $80 \%$ de aminoácí 

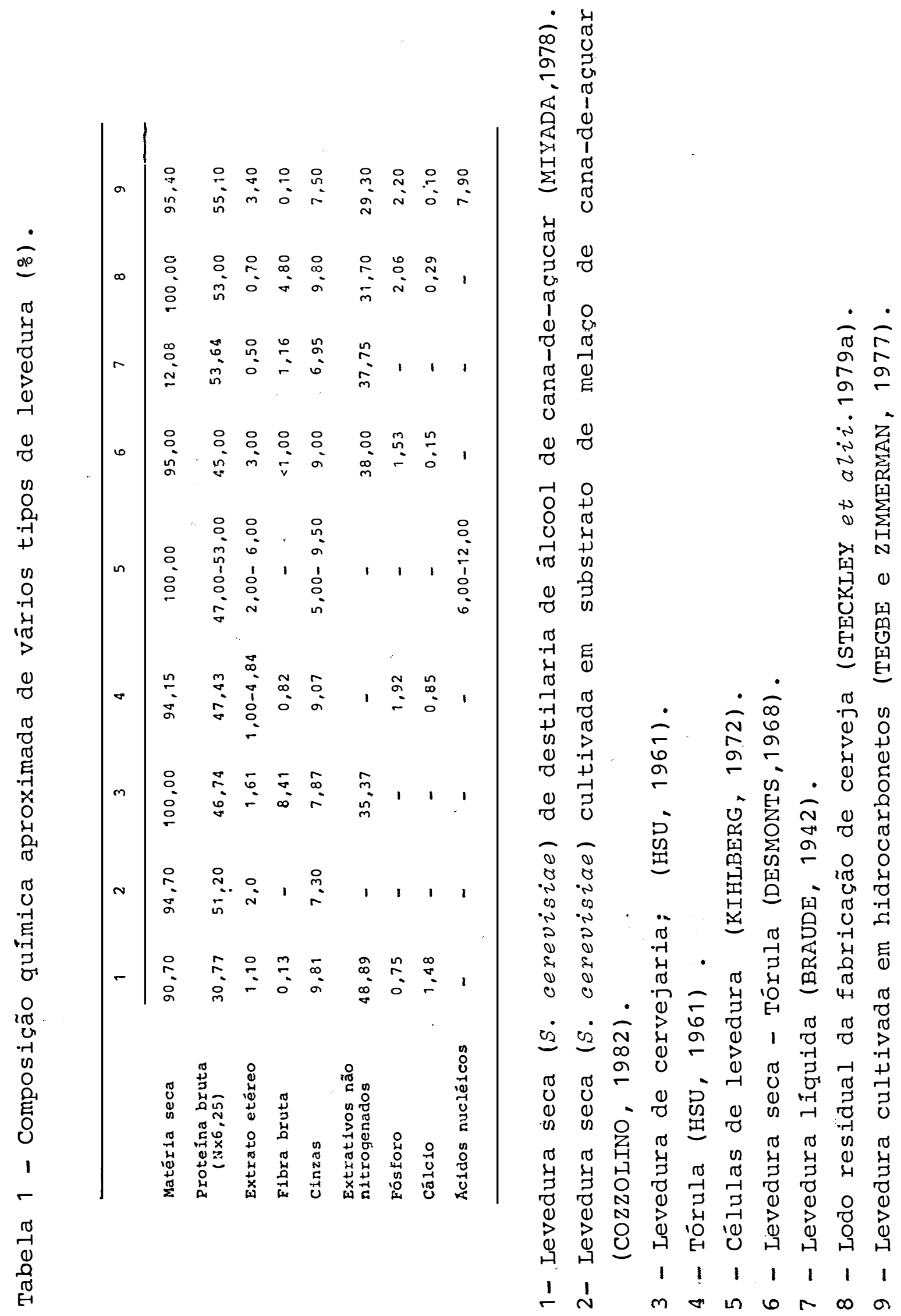
dos , 12\% de ácidos nucléicos e 8\% de amônia; cerca de $7 \%$ do nitrogênio total ocorre como aminoácidos livres, e em outros compostos, tais como glutationa, lecitina, ácido adenilico, vi taminas, enzimas e coenzimas em pequenas quantidades (PEPPLER, 1970) .

As células de levedura possuem teor de pro teína bruta comparável àqueles encontrados nos suplementos pro téicos de origem animal. Todavia, KIHLBERG (1972) salienta que na determinação da proteina bruta considera-se que todo nitro gênio celular se encontra na forma protéica, mas principalmen te no caso dos microorganismos isto não ocorre, pois 20 a $30 \%$ do nitrogênio celular é não proteíco, e encontra-se presente nos compostos como ácidos nucléicos,glucosamina, galactosamina, etc., sendo que nas leveduras o nitrogênio presente nas bases púricas e pirimídicas dos ácidos nucléicos, representam 10 a 15\% do nitrogenio celular.

Quanto à composição em aminoácidos,as leveduras são ricas em lisina e treonina (DESMONTS,1968), porém po bres em metionina (DESMONTS, 1968; HSU, 1961).

Trabalhando com biomassa protéica de Saccharomyces cerevisiae cultivadas em melaço, COzzolino (1982) determinou os aminoácidos limitantes deste concentrado protéico e obser vou, em relação às proteínas do ovo, uma "limitação primária" de sulfurados totais (metionina e cistina), seguida de triptofano e aromáticos totais (fenilalina e tirosina). Por outro lado, quando comparou a biomassa com a caseina, que é uma proteína 
deficiente em aminoácidos sulfurados, observou uma "limitação primária" em aromáticos totais seguidos de triptofano e leucina. A Tabela 2 mostra a composição em aminoácidos de varias leveduras, em comparação com o farelo de soja. Observa-se, de modo geral, que as leveduras em termos de qualida de protéica são semelhantes e até mesmo superiores ao farelo de soja.

Os carboidratos constituem $22 \%$ a $34 \%$ da matéria seca. Esta variação se deve à composição do meio de cultura e do nível de anaerobiose mantido neste meio. Para um teor de 25\% de carboidratos, $94 \%$ destes foram recuperados sob quatro fra ções diferentes: 33\% de trealose, que é um dissacarideo não re dutor formado pela ligação de duas moléculas de glicose ; 27\% de glucanas que representam a celulose das leveduras e $21 \%$ de mananas que representam a goma das leveduras. As glucanas e ma nanas são polisscarídeos não redutores, presentes na parede celular das leveduras e formados por duas moléculas de glicose, e duas de manose respectivamente e, 12\% de glicogênio, que é um polissacarídeo de reserva formado por moléculas de glicose e idêntico ao glicogênio de origem animal (PEPPLER,1970).

A fração lipídica é muito variável: 7\% do pêso sêco em S. cerevisiae, atingindo até $50 \%$ em Rhodotórula gracilis (ALMEIDA, 1962). No entanto; MACHADO (1983) cita que de acordo com a maioria dos autores a fração extrato etéreo va ria de $1 \%$ a $6 \%$ do peso seco. PEPPLER (1970) menciona que os triglicerídeos, lecitina e ergosterol são os maiores constituin 
Tabela 2 - Porcentagens de proteína bruta e aminoácidos de vários tipos de leveduras em comparação con o farelo de soja.

\begin{tabular}{|c|c|c|c|c|c|c|}
\hline Aminoácidos & 1 & 2 & 3 & 4 & 5 & 6 \\
\hline & \multicolumn{6}{|c|}{$\ldots \ldots \ldots \ldots \ldots \ldots \ldots \ldots \ldots \ldots \ldots$} \\
\hline PB & 30,77 & 51,20 & 55,10 & 46,74 & 47,43 & 46,00 \\
\hline Lisina & 1,87 & 4,65 & 3,60 & 7,10 & - & 2,98 \\
\hline Triptofano & - & 0,53 & 0,80 & 1,20 & 0,66 & 0,84 \\
\hline Metionina & 1,27 & 1,00 & 0,60 & 2,70 & 0,84 & 0,52 \\
\hline Treonina & 1,57 & 2,45 & 1,90 & 5,50 & 2,58 & 1,99 \\
\hline Histidina & 0,47 & 1,33 & 1,40 & 3,30 & 1,31 & 1,16 \\
\hline Fenilalanina & 1,06 & 1,99 & 2,30 & 4,50 & 2,41 & 2,04 \\
\hline Arginina & 0,98 & 2,66 & 1,80 & 3,10 & 3,61 & 3,06 \\
\hline Leucina & 2,02 & 3,33 & 3,80 & 7,30 & 4,14 & 3,73 \\
\hline Isoleucina & 1,37 & 2,37 & 2,80 & 6,00 & 3,75 & 2,67 \\
\hline Valina & 1,97 & 3,11 & 3,10 & 5,30 & 2,89 & 2,50 \\
\hline Serina & 0,94 & 2,43 & - & - & - & - \\
\hline Prolina & 0,90 & 1,87 & - & - & - & - \\
\hline Glicina & 1,45 & 2,46 & - & - & 0,22 & - \\
\hline Alamina & 1,87 & 3,17 & - & - & - & - \\
\hline Cistina & - & - & - & 1,10 & 0,68 & 0,60 \\
\hline Ácido aspártico & 3,06 & 5,40 & - & - & - & - \\
\hline Acido glutāmico & 4,08 & 10,14 & - & - & 6,90 & - \\
\hline Tirosina & 0,87 & $1 ; 62$ & - & 3,80 & - & 0,87 \\
\hline
\end{tabular}

1 - Levedura seca (S. cerevisiae) de destilaria de álcool (MYIADA, 1978).

2 - S. cerevisiae cultivada em melaço (COZZOLINo, 1982)

3 - Levedura cultivada em hidrocarbonetos ( TEGBE e ZIMMERMAN, 1977).

4 - Levedura de cervejaria (HSU, 1961).

5 - Levedura Tarula (HSU, 1961).

6 - Farelo de soja (CAMPOS, 1981). 
tes dos lipídios das leveduras, predominando os triglicerídeos dos ácidos oléico e palmítico.

A cinza representa de 6 a $8 \%$ do peso seco, sendo a maior parte constituida de potássio e fósforo, encontrando-se em menores quantidades cálcio,magnésio, sódio, enxofre, zinco, ferro, cobre, chumbo, manqanês e iodo ( PEPPLER, 1970 ).

Quanto às vitaminas, as leveduras são pratica mente desprovidas das vitaminas A e C (DESMONTS,1968 e JACQUOT, 1943); contém vários tipos de esteróis, sendo que o ergosterol representa $0,56 \%$ do peso seco e pode ser transformado em vitamina. $\mathrm{D}_{2}$ através da irradiação ultravioleta (HSU, 1961). São ricas em vitaminas do complexo B (ENSMINGER, 1970 e HSU, 1961) princí palmente niacina e riboflavina (HSU,1961), mas são pobres em cianocobalamina ou vitamina $B_{12}$ (COzZOLINO, 1982 e VANANUVAT, 1977).

As leveduras possuem, também fatores ainda não identificados (ENSMINGER, 1977).

Segundo DESMONTS (1968), a composição das levedu ras pode variar com a espécie, o substrato em que são cultiva das, o método de fermentação, o momento e as condições de seca gem e também com a idade das células; sendo o substrato em que se desenvolvem o : fator de maior influência ( HSU, 1961). 


\section{$2.3 .2 .:$ UミO NA ALIMENTAÇÃO}

O emprego das leveduras na alimentação se justi fica como fonte de substância protéica, sais minerais e sobre tudo por sua riqueza em vitaminas do complexo B (IIMA, 1966). Porém, pode-se afirmar que em nossas condições, a proteína é o nutriente de maior interesse nas leveduras.

Sabe-se que os aminoácidos presentes na fração protéica de um alimento. fornece valiosas informações sobre o valor nutricional potencial deste alimento, uma vez que a qua lidade da proteína é função do seu ballanceamento adequado em aminoácidos, principalmente em aminoácidos essênciais. Porém, KIHLBERG (1972) salienta que a composição em aminoácidos nem sempre reflete a disponibilidade fisiológica dos mesmos; por isso, os ensaios biológicos são também importantes, pois complementam a análise química na avaliação do valor nutritivo.

A maioria dos ensaios biológicos visando deter minar o valor nutritivo das leveduras foi feita com ratos. Assim, analisando-se os trabalhos de SHACKLADY e WALKER (1973) e SALES et alii (1977), observou-se que o valor biológico das leveduras sem suplementação com metionina foi de $57 \%$, valor este, inferi or ao do farelo de soja (68\%). Todavia a suplementação com me tionina resultou numa elevação deste indice para $90 \%$, chegando inclusive a ultrapassar o valor biológico da farinha de peixe (80\%). Este fato vem comprovar a deficiência das leveduras em aminoácidos sulfurados. Verificou-se também que a digestibilí 
dade verdadeira do nitrogênio das fontes protéicas estudadas foi igual ou maior a $80 \%$, sendo que a levedura chegou a ser superi or a $90 \%$

COZZOLINO (1982), alimentando ratos com rações cuja fonte pretéica era biomassa de $S$. cerevisiae ou caseína, obteve respectivamente os seguintes indices : digestibilidade aparente do nitrogênio $80 \%$ e $90 \%$ e, valor biológico $79 \%$ e $84 \%$. Observa-se que a levedura embora inferior, está bem próxima da caseína, a qual é considerada uma proteína de alta qualidade.

Os trabalhos experimentais com o objetivo de vê rificar a viabilidade do fornecimento de levedura liquida para ruminantes são escassos. A maioria visa o fornecimento de pe quenas quantidades, geralmente sob a forma seca.

GRIEVE (1979), com o objetivo de determinar a aceitabilidade da levedura liquida de cervejaria, por novilhos em crescimento, forneceu a mesma de três maneiras diferentes : a) livre escolha (separada da ração basal); b) pulverizada so bre a ração basal, em quantidade suficiente para suprir as exí gências de proteína, segundo $N R C, c)$. isturada na ração basal na mesma quantidade de b. Observou-se que a ingestão de maté ria seca total foi maior em "c" do que em "b" sendo que em "a" houve alta ingestão de leveduras $(8,4 \mathrm{Kg} / \mathrm{cab} / \mathrm{dia})$ e consequen te redução na ingestão de ração basal. Os ganhos de peso médio foram de $0,89,0,93$ e $1,05 \mathrm{Kg} / \mathrm{cab} / \mathrm{dia}$, para os tratamentos a, b e c respectivamente. 
Ainda GRIEVE (1979), para avaliar a levedura li quida de cervejaria como suplemento protéico, para novilhas em crescimento, substituiu o farelo de soja pela levedura em dietas com 13\% de proteina bruta e não encontrou diferença na inges tão de matéria seca e no ganho de peso.

BRAUDE (1942) verificou que o fornecimento de levedura líquida para vacas em lactação, na quantidade de 11 a $17 \mathrm{~kg} / \mathrm{cab} / \mathrm{dia}$, como fonte de proteina, elevou a produção de leite e o teor de gordura, em relação aos animais controle que receberam sementes de colza. Ao fornecerem levedura líquida para vacas em lactação: PETRAITIS e BARANAUSKAS (1971) também observaram aumentos na produção, no teor de gordura e na proteína do leite, porém estes aumentos não foram significativos.Em outros trabalhos (STECKLEY et alii, 1979b;STYCZNSKI, 1966, TOMLINSON et alii, 1977), o emprego da levedura liquida não teve efeito sobre a produção e teor de gordura do leite.

A inclusão de levedura na dieta parece afetar a digestibilidade dos nutrientes. Assim STECKLEY et alii (1979b) e MACHADO (1983) observaram, nas dietas com levedura, um aumen to na digestibilidade aparente da matéria seca, energia bruta, proteína bruta e também da fibra (STECKLEY et alii, 1979b), enquanto que BEESON e PERRY (1952) e LEGENDRE et alii (1957) não observaram diferenças estatísticas nas digestibilidades dos nutrientes.

Quanto à palatabilidade, GRIEVE (1979) classifí cou a levedura como altamente palatável, já que obteve consumo 
de $8,4 \mathrm{Kg} / \mathrm{cab} / \mathrm{dia}$. Também STREETER et a $i$ i (1980) observaram aumentos na ingestão de minerais e no ganho de peso, em bovinos, quando a levedura era adicionada aos blocos de minerais.

Observa-se, pelo exposto, que embora os resulta dos sejam um pouco discordantes, a levedura pode substituir as fontes protéicas de origem vegetal nas dietas dos ruminantes.

\subsubsection{EEEITO TÓXICO DA LEVEDURA}

Para que um alimento seja introduzido na alimen ção humana e animal, é necessário que se conheça, além de seu valor nutricional, a sua inocuidade.

No caso das leveduras, além da biomassa, deve-se estar atento também aos substratos em que se desenvolvem prin cipalmente os hidrocarbonatos; os quais podem deixar residuos nas células, tornando-as portanto, impróprias para consumo hu mano (BUNKER; 1968).

Trabalhando com biomassa de saccharomyces cerevisiae, cultivada em melaço, Cozzolino (1982) alimentou sucessivas gerações de ratos e não observou problemas de ordem toxicológica.

PEIXOTO e MATTOS (1972), utilizando marrequinhos de um dia, substituiram $0,1,2,4$ e $8 \%$ da ração comercial por lo do residual das domas de fermentação alcólica, e não constataram sintomas de intoxicação e alterações macroscópicas nos orgãos intemos (çoração, 
pulmões, fígado, intestinos e baço), quatro semanas após apli cação dos tratamentos.

\subsection{PROCESSOS DE CONSERVAC,ÃO DAS LEVEDURAS}

A literatura é muito escassa com referência à tecnologia de conservação da levedura líquida, destinada à alí mentação animal.

Sabe-se que o manejo de um alimento sob a forma seca, como por exemplo: transporte, armazenamento, mistura com outros ingredientes, assim como o seu fornecimento para os ani mais,é menos trabalhoso do que o manejo de um alimento líquiảo. Todavia, a secagem envolve uso de energia e investimento com equipamentos, $\quad$ que poderá elevar o custo do pro duto.

Caso a implantação das microdestilarias fosse concretizada pelo governo, o fator transporte tornar-se-ia menos importante, devido à provável distribuição das microciestila rias a distâncias mais próximas dos usuários da levedura.

Com o objetivo de conservar a levedura úmida para a alimentação animal NAMORY (1975), realizou um ensaio com uma suspensão de células de leveduras, utilizando seis tratamen tos: ácido clorídrico, acético, lático e propiônico, metabisul fito de potássio e formaldeído a $30 \%$, a base de $1 ; 4 ; 4 ; 6$; 2 e 2g/litro de levedura, em cada tratamento. No final de oito dias, verificou que o ácido clorídrico e o formaldeído foram 
os agentes mais eficazes na conservação, havendo redução do número de células e ausência de odores fétidos. Para pro longar o armazenamento por 15 dias ou mais, foi necessário aumentar as do ses dos conservantes utilizados, e observou que o ácido propiōnico (10g/1) foi o menos eficaz e o ácido clorídrico ( $1 \underline{g / 1}$ ) foi o mais eficaz.

Em outro experimento, NAMORY (1975) misturou áci do clorídrico $(1 \mathrm{~g} / 1)$ com $2 \mathrm{~g} / 1 \mathrm{litro}$ de cada um dos outros produ tos (ácido acético, propionico, butirico, metabisulfito de po tássio e formol), formando cinco tratamentos. No final de dois meses de armazenamento, observou uma diminuição pronunciada do número de células vivas, sem o exalamento de odores fétidos e sem o desenvolvimento de fungos. A mistura de ácido clorídrico com formol mostrou-se a mais eficaz.

Trabalhando com levedura de cerveja, e usando como agentes conservantes o ácido clorídrico ou sulfúrico, ou uma mistura de ambos, RAFF (1967) baixou o pH para 2,5 - 3,5 e observou no final de nove semanas de armazenamento, uma dimi nuição na degradação das proteínas e inibição do crescimento bacteriano.

Um outro método de conservação de leveduras es tudado por NAMORY (1975) foi o da ensilagem, ou seja, amostras do creme de leveduras previamente aquecidas a $75^{\circ} \mathrm{C}$ durante 5 minutos e depois resfriados, foram semeadas com uma cepa de Lactobacizlus plantarum à base de $3 \times 10^{2}$ germes/ml. Em seguida as amostras foram tratadas com diferentes agentes químicos láci do clorídrico, acético, lático ou formolb ou semeadas com bac 
térias de contaminação ( Bacizlus cereus e clostridium sporogenes ). Ao final de 15 dias observou que a levedura não contaminada havia se conservado bem, apresentanđ̃o cheiro agradável , além da presença de pelo menos $10^{6}$ bactérias por mililitro. Em presença de ácido clorídrico (1g/1), de ácido acético (2g/1) e ácido lático (2g/l), a multiplicação de L. plantarum não foi afetada, apesar do $\mathrm{pH} 3 ; 0 ; 3,0$ e 3,2 respectivamente. Na pre sença de formol $(1 \mathrm{~g} / 1)$ não encontrou bactérias recuperáveis.Nas amostras contaminadas por $B$. cereus e $C$. sporogenes a ação do L. plantarum foi benéfica, não ocorrendo odores desagradáveis. STECKLEY et alii (1979a) estudaram o efeito da temperatura $\left(4,4 ; 21,0\right.$ e $\left.30,0^{\circ} \mathrm{C}\right)$ e do tempo de armazenamento $(0 ; 7,14,21,28$, e 36 dias) sobre a composição nitrogenada do lodo ou borra da levedura de cervejaria. Os autores observaram que os conteúdos de matéria seca e proteina verdadeira decres ceram 1 inearmente aos 35 dias de armazenagem a $4,4^{\circ} \mathrm{C}$, enquanto que para as temperaturas mais elevadas houve um decréscimo râ pido para matéria seca e proteína verdadeira até os 7 e 14 dias respectivamente, havendo a partir destes dias uma estabili dade em ambos os parâmetros.

A proteina bruta e amônia variaram inversamente com a matéria seca. A solubilidade do nitrogênio permaneceu constante a $4,4{ }^{\circ} \mathrm{C}$, enquanto para temperaturas mais altas au mentou linearmente até o 149 dia, depois também estabilizou . Observaram também que a redução do número de células vivas foi rápida à temperaturas mais altas e lenta a $4,4^{\circ} \mathrm{C}$. 
Em outro experimento STECKLY et alii (1979a) es tudaram o efeito de uma mistura de ácido acético e propionico (AP) a 1\% vol/vol e uma mistura de AP com ácido fórmico e for maldeido (APFF) também a 1\% vol/vol e, do tempo de armazenamen to $(0,14,28$ e 42 dias) sobre a borra de levedura. Observaram uma menor redução do teor de matéria seca, pela presença dos aditivos, sendo a mistura APFF a mais efetiva. A proteina bru ta teve um rápido aumento até os 14 dias e depois permaneceu constante. A proteína verdadeira decresceu bruscamente até o 149 dia, a partir dai a queda foi menos intensa, para todos os tratamentos, e a solubilidade do nitrogênio teve comportamen to inverso. O teor de nitrogênio amoniacal foi baixo, mas aumen tou linearmente através do tempo para o tratamento APFF e qua draticamente para o controle e AP.

Para que as leveduras possam ser empregadas de modo seguro na alimentação, alguns autores ( JACQUOT, 1943 ; JARDIM , 1976; NAMORY, (1975) recomendam que as mesmas devam ser tratadas, com o objetivo de se obter a lise das células, a fim de serem evitadas perturbações digestivas decorrentes de fer mentações anormais no aparelho digestivo. DESHONTS (1968) tam bém recomenda a morte e secagem das leveduras, pois leveduras ví vas, quando introduzidas no aparelho digestivo, tem a tendên cia de absorver as vitaminas do bolo alimentar, comportando-se como parasitas, podendo provocar verdadeiras avitaminoses, ape sar do teor vitamínico que possuem. Entretanto LEGENDRE (1957) e GRIEVE (1979) não observaram efeitos colaterais ao fornecerem 
leveduras vivas para ruminantes.

Sob a temperatura de $71^{\circ} \mathrm{C}$ por 7 minutos ou $75^{\circ} \mathrm{C}$ por 1 minuto NAMORY (1975) conseguiu desativar as leveduras. Se gundo MARTELLI (1962), as temperaturas de esterilização para as leveduras são: calor seco, 110 a $115^{\circ} \mathrm{C}$ por 1,5 horas e 115 a $120^{\circ} \mathrm{C}$ por 1,0 hora, e, calor úmido, de 60 a $70^{\circ} \mathrm{C}$ por 15 minutos e $100^{\circ} \mathrm{C}$ por 20 minutos para as formas celular e esporos respec tivamente. 


\section{MATERIAL E METODOS}

O trabalho foi conduzido no Laboratório de Bro matologia do Departamento de Zootecnia da Escola Superior de Agricultura "Luiz de Queiroz" (ESALQ) Piracicaba, Estado de São Paulo.

A levedura utilizada foi obtida na Usina Santa Bárbara em Santa Bárbara D'Oeste, Estado de São Paulo. As leve duras de recuperação, do gênero saccharomyces, foram obtidas pelo desvio de uma parte do leite de leveduras recuperado por centrifugação, e que se destinava às dornas de fermentação. o esquema da Figura 1 ilustra resumidamente o processo de produ ção de açucar e álcool bem como a obtenção das leveduras.

o delineamento experimental utilizado foi o de blocos ao acaso em parcelas subdivididas, sendo que as parce las representavam os tratamentos e as subparcelas as épocas de amostragens . 


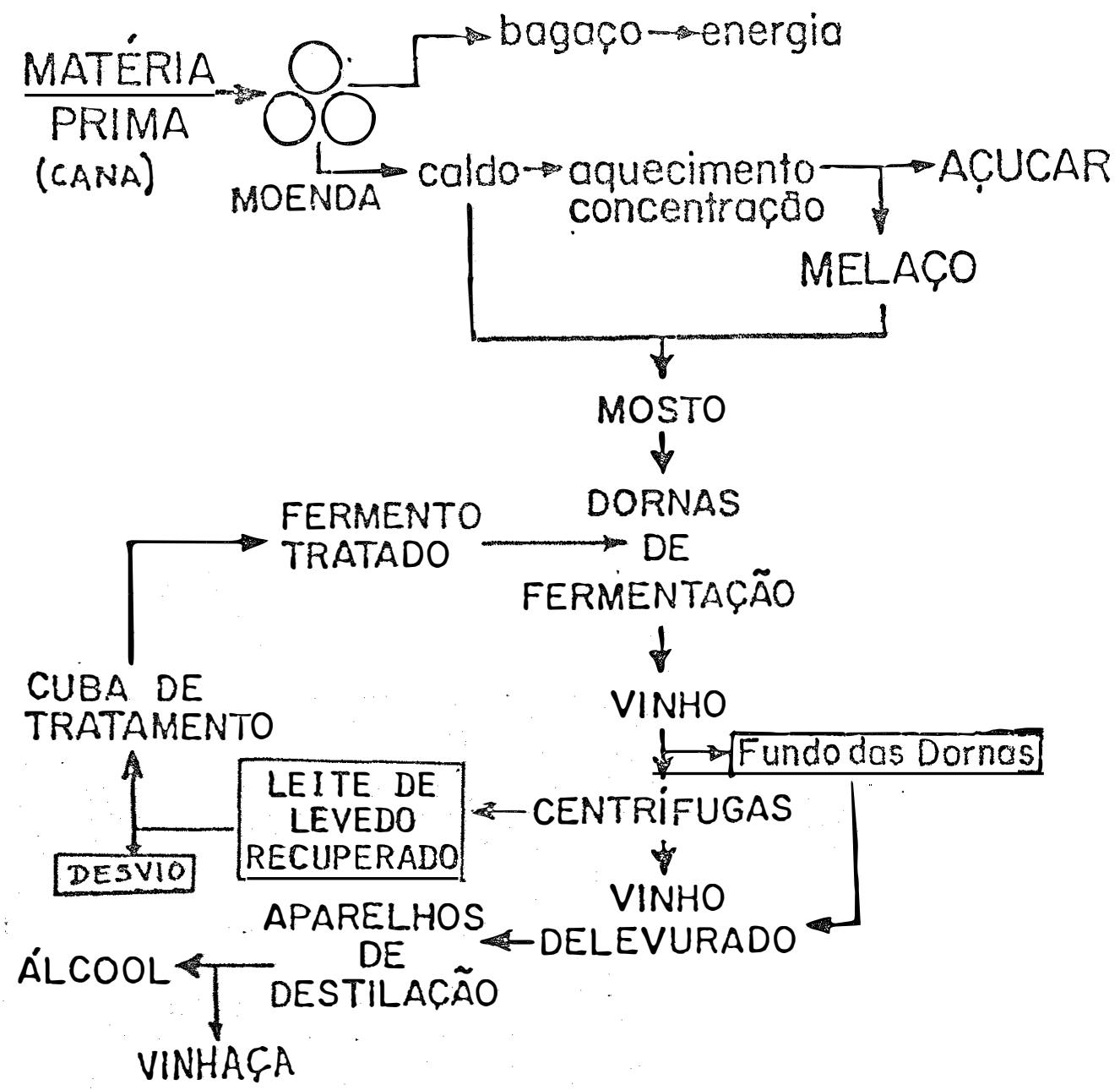

Figura 1 - Esquema do processo de produção de açucar e álcool e da recuperação da levedura (Fonte: AMORIM e MATTOS, 1982). 


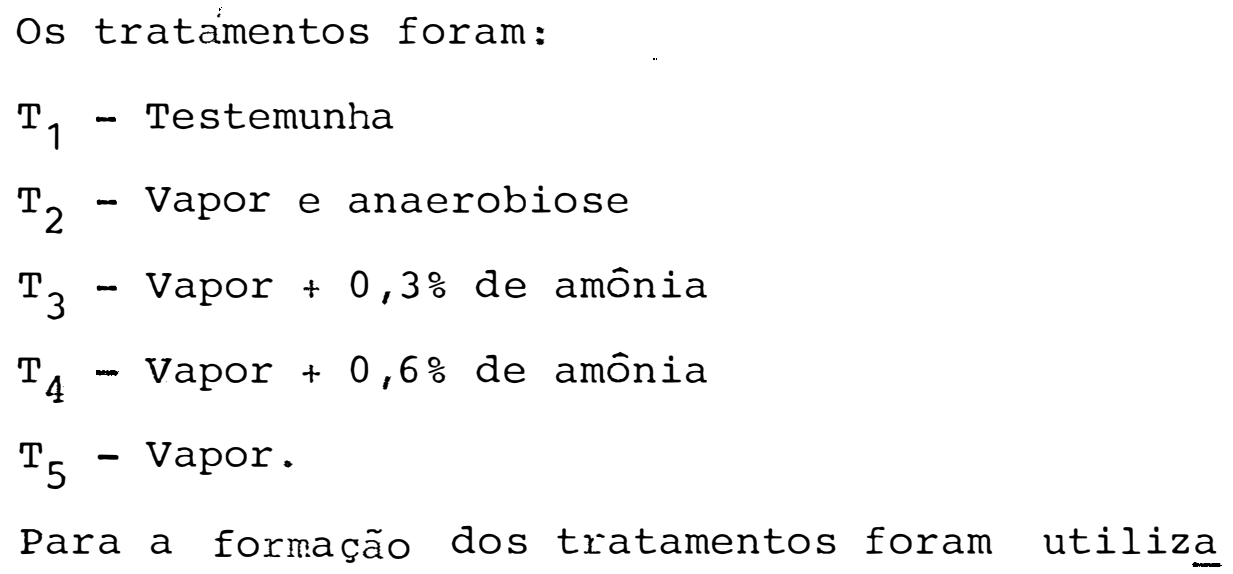
dos baldes plásticos, com capacidade para oito litros, exce to o tratamento dois para o qual usou-se galão com tampa, sendo que a quantidade de levedura usada foi de 5 litros por trata mento.

Após aplicação de 10 minutos de vapor aguardouse o resfriamento do material e então injetou-se $\mathrm{CO}_{2}$ para com pletar o tratamento dois e vedou-se hermeticamente; para com pletar os tratamentos três e quatro, adicionou-se respectiva mente $60 \mathrm{ml}$ e $120 \mathrm{ml}$ de hidróxidọ de amônia (P.A. com 25\% $\mathrm{NH}_{3}$ ). Este procedimento foi realizado por três semanas consecutivas, constituindo-se, portanto, as três repetições usadas no experi mento.

As amostragens que coincidiram com os tempos de armazenamento foram realizadas nos dias $0,7,14,21$, e 28 após aplicação dos tratamentos. As amostras foram embaladas em vidros e armazenadas em Freezer a $-20^{\circ} \mathrm{C}$.

Para avaliar os efeitos dos tratamentos e dos tempos de armazenamento sobre as leveduras, foram feitas as seguintes determinações: matéria seca a $105^{\circ} \mathrm{C}$, nitrogênio total 
(NT); nitrogênio solúvel (NS), nitrogênio não protéico (NNP) e nitrogênio amoniacal (NA), segundo os métodos descritos por CROOKER et alii (1978) BUTOLO (1979) e BAILEY (1967) respectivamente, além das medidas do $\mathrm{pH}$.

A determinação do NS constou dos seguintes pas sos: Tomou-se uma quantidade de amostra contendo $50 \mathrm{mg}$ de $\mathrm{n} \underline{i}$ trogênio e adicionou-se $200 \mathrm{ml}$ de uma solução de $\mathrm{NaCl}$ a $0,87 \%$ $\left(8,8545 \mathrm{~g} /\right.$ litro de água destilada), pré-aquecida a $40^{\circ} \mathrm{C}$ e com pH ajustado para 6,5 com ácido ortofosfórico 85\%. Esta mistura contida em erlenmeyer foi incubada a $40^{\circ} \mathrm{C}$ sob agitação constan te por uma hora. Em seguida filtrou-se em papel Whatman no 4 e numa aliquota de $50 \mathrm{ml}$ do filtrado determinou-se o NS pelo mé todo de Kjeldhal e expresso como uma porcentagem do NT.

Para determinação do NNP, foi tomada uma amos tra contendo aproximadamente $5 \mathrm{~g}$ de matéria seca $( \pm 30 \mathrm{ml})$ e adicionou-se $50 \mathrm{ml}$ de água destilada e agitou-se durante $10 \mathrm{mi}$ nutos. Após 30 minutos de repouso adicionou-se $50 \mathrm{ml}$ de uma so lução de ácido tricloroacético (TCA) a $10 \%$ e deixou-se em re frigerador por 3 horas. Em seguida filtrou-se em papel de fil tro faixa branca e em $10 \mathrm{ml}$ do filtrado foi determinado o NNP pelo método de Kjeldhal e expresso como porcentagem do NT.

O NA foi determinado através da destilação dire ta de $10 \mathrm{ml}$ da amostra, usando-se $15 \mathrm{ml}$ de $\mathrm{NaOH}$ a $50 \%$ e foi ex presso como uma porcentagem do NT. 


\section{RESULTADOS E DISCUSSAO}

\subsection{COMPOSICÃO DA LEVEDURA UTILIZADA}

As Tabelas 3,4 e 5 apresentam os resultados das análises químicas efetuadas na levedura utilizada neste estudo.

Confrontando-se os dados da Tabela 3 com os da dos encontrados na literatura (Tabela 1), observa-se que, ape sar do teor protéico elevado da levedura, resíduo da produção de álcool, este valor está abaixo dos encontrados em outros ti pos de levedura; os teores de extrato etéreo e de fibra bruta são próximos àqueles encontrados na literatura. Os teores de cinza e extrativo não nitrogenađos são mais elevados na levedura em questão. Essas diferenças pođeru ser cievidas à contaminação do meio de cultura e ao tipo de substrato em que se ajesenvolveu a levedura usada neste experimento, assim como a possíveis variações nas próprias análises.

$$
\text { Quanto à composição em aminoácidos, apresentada }
$$




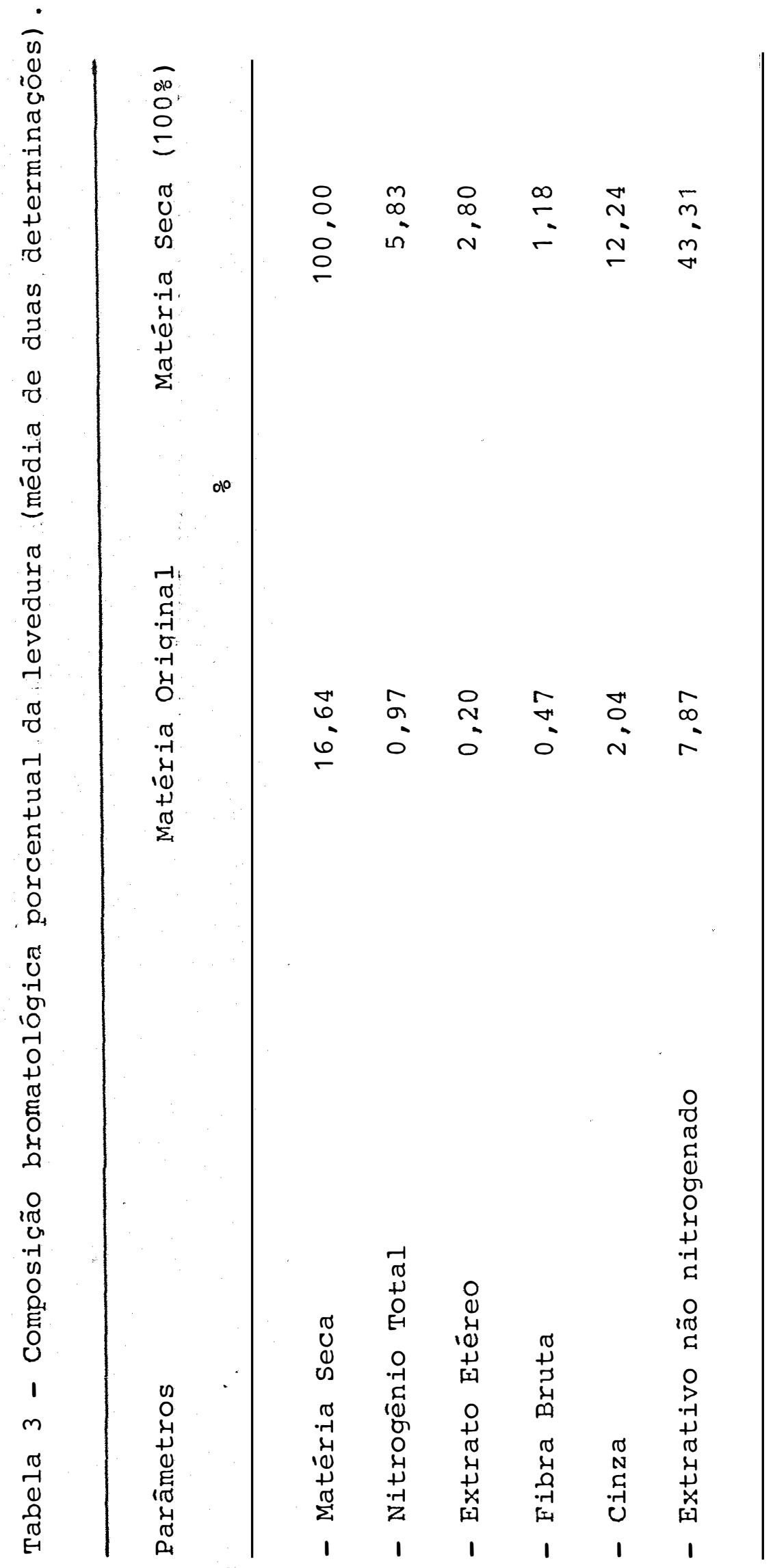


Tabela 4 - Composição da levedura em aminoácidos.

\begin{tabular}{|c|c|}
\hline Aminoácidos & Quantidade \\
\hline Essenciais & $\mathrm{g} / 100 \mathrm{~g}$ de Proteina \\
\hline Lisina & 4,97 \\
\hline Histidina & 2,00 \\
\hline Arginina & 3,69 \\
\hline Treonina & 4,22 \\
\hline Valina & 4,76 \\
\hline Metionina & 3,57 \\
\hline Leucina & 5,44 \\
\hline Isoleucina & 3,49 \\
\hline Fenilalanina & 3,49 \\
\hline Subtotal : & 35,63 \\
\hline Não essenciais & - \\
\hline Alanina & 4,87 \\
\hline Glicina & 3,65 \\
\hline Prolina & 3,39 \\
\hline Serina & 4,24 \\
\hline Asparagina & 8,30 \\
\hline Glutamina & 10,69 \\
\hline Tirosina & 1,50 \\
\hline Subtotal & 36,64 \\
\hline Total & 72,94 \\
\hline
\end{tabular}


Tabela 5 - Composição da levedura em minerais.

Minerais

응

Nitrogênio

4,42

Fósforo

1,07

Potássio

2,33

Cálcio

0,78

Magnésio

0,29

Enxofre

0,48

ppm

Ferro

$3.477,00$

Cobre

39,30

Manganês

102,00

Zinco

699,50

Boro

$<5,00$

Molibdênio

$-$

Sódio

148,50

Alumínio

$6.590,00$

Cobalto

Cloro 
na Tabela 4, observa-se uma ligeira superioridade desta levedu彑 ra sobre outras encontradas na literatura. Todavia, há uma va riação em função do tipo de levedura e do substrato em que se desenvolveu.

Com relação aos minerais (Tabela 5), os teores de ferro, manganês, zinco e alumínio, principalmente, são mui to superiores àqueles encontrados por MACHADO (1983), ou seja, ferro 518 ppm,manganês 38 ppm, zinco 95 ppm e alumínio 497 ppm. Os altos teores desses elementos na levedura estudada podem ser devido a alguma ferrugem ocorrida nas dornas de fermentação ou à contaminação em outros equipamentos por onde passa a levedu ra durante o processo de fabricação do álcool.

\subsection{TEORES DE MATÉRIA SECA}

Na Tabela 6 estão apresentados os dados sobre os teores de matéria seca da levedura $(1050 \mathrm{C})$, referente aos diferentes tratamentos e tempos de armazenamento.

A análise de variância apresentada na Tabela 7 mostra diferenças significativas $(P<0,01)$ para o tempo de ar mazenamento, bem como para a interação "tratamento $x$ tempos de armazenamento". O desdobramento dos graus de liberdade tempos de armazenamento dentro de tratamento mostra diferenças sign $\underline{i}$ ficativas $(p<0,01)$ para todos os tratamentos, exceto para o tratamento 2 . 


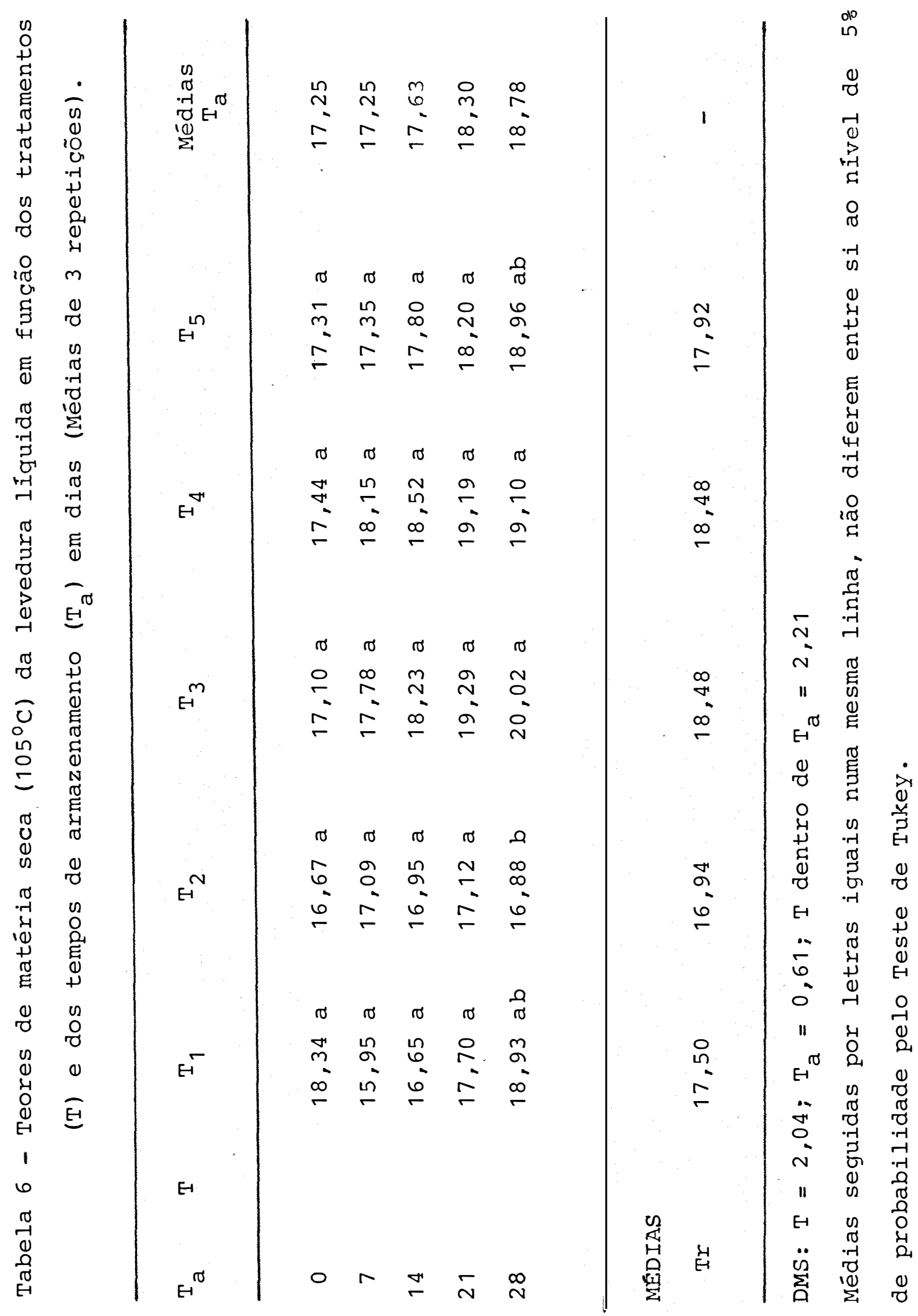


Tabela 7 - Análise de variância para os teores da matéria se ca da levedura líquida em função dos tratamentos (T) e dos tempos de armazenamento $\left(\mathrm{T}_{\mathrm{a}}\right)$.

\begin{tabular}{|c|c|c|}
\hline Fontes de variação & G.I. & QM \\
\hline Bloco & 2 & $4,75^{\mathrm{NS}}$ \\
\hline Tratamento (T) & 4 & $6,56^{\mathrm{NS}}$ \\
\hline Residuo (A) & 8 & 2,61 \\
\hline Parcela & 14 & \\
\hline Tempo de armazenarnento $\left(\mathrm{T}_{\mathrm{a}}\right)$ & 4 & $6,36^{* *}$ \\
\hline Interação $T \times T_{a}$ & 16 & $1,34^{* *}$ \\
\hline $\mathrm{T}_{\mathrm{a}}$ dentro de $\mathrm{T}_{1}$ & 4 & $4,54^{\star \star}$ \\
\hline$T_{a}$ dentro de $T_{2}$ & 4 & $0,09^{\mathrm{NS}}$ \\
\hline $\mathrm{T}_{\mathrm{a}}$ dentro de $\mathrm{T}_{3}$ & 4 & $4,12^{\star \star}$ \\
\hline $\mathrm{T}_{\mathrm{a}}$ dentro de $\mathrm{T}_{4}$ & 4 & $1,56^{\star *}$ \\
\hline$T_{a}$ dentro de $T_{5}$ & 4 & $1,40^{\star *}$ \\
\hline$T$ dentro de $T_{0}$ & 4 & $1,13^{\mathrm{NS}}$ \\
\hline $\mathrm{T}$ dentro de $\mathrm{T}_{7}$ & 4 & $2,19^{\mathrm{NS}}$ \\
\hline $\mathrm{T}$ dentro de $\mathrm{T}_{14}$ & 4 & $1,96^{\mathrm{NS}}$ \\
\hline$T$ dentro de $T_{21}$ & 4 & $2,65^{*}$ \\
\hline $\mathrm{T}$ dentro ce $\mathrm{T}_{28}$ & 4 & $3,98^{\star \star}$ \\
\hline Residuo (B) & 40 & 0,35 \\
\hline Total & 74 & \\
\hline
\end{tabular}

IV Caso SATTERTHWATE : GL $\mathrm{T}$ dentro de $\mathrm{T}_{\mathrm{a}}=18$ QMR $\mathrm{T}$ dentro de $\mathrm{T}_{\mathrm{a}}=0,80$

C.V. : Residuo $A=9,05 \%$, Residuo $B=3,31 \%$ ** Significativo ao nivel de $1 \%$ de probabilidade * Significativo ao nivel de $5 \%$ de probabilidade ${ }^{N S}$ Não significativo. 
As equações de regressão, juntamente com os res pectivos pontos de máximo, pontos de mínimo, pontos de infle xão e coeficientes de determinação, são apresentados na Tabela 8 e ilustrados na Figura 2. Verifica-se que o teor de matéria seca no tratamento testemunha $\left(\mathrm{T}_{1}\right)$ teve um comportamento cúbi co ou seja, decresceu inicialmente atingindo um mínimo aos 9 dias e elevou-se novamente, atingindo um valor máximo aos 29 dias de armazenamento. Este resultado também foi observado por STECKLEY et alii (1979a) os quais atribuiram o decréscimo in cial à fermentação contínua do substrato remanescente e dos carboidratos das células endógenas,pela levedura viva. O aumen to nos últimos dias de armazenamento foi atribuído à evapora ção. Quanto ao tratamento dois, o teor de matéria seca mante ve-se constante, já que as condições anaeróbicas do mesmo não permitiram variações no seu teor de umidade. Para os tratamen tos três, quatro e cinco, o teor de matéria seca aumentou line armente com o tempo de armazenamento, o que pode ser explicado pela ausência de fermentação e pela perda de água do material.

O desdobramento dos graus de liberdade dos tra tamentos dentro de cada tempo de armazenamento é apresentado na Tabela 7. Observa-se que para os três primeiros tempos de armazenamento $(0,7$ e 14 dias) os teores de matéria seca fo ram estatisticamente iguais nos diferentes tratamentos. Para o tempo de 21 dias houve diferenças $(p<0,05)$ entre os trata mentos, embora tal fato não tenha sido comprovadoquando se apli 


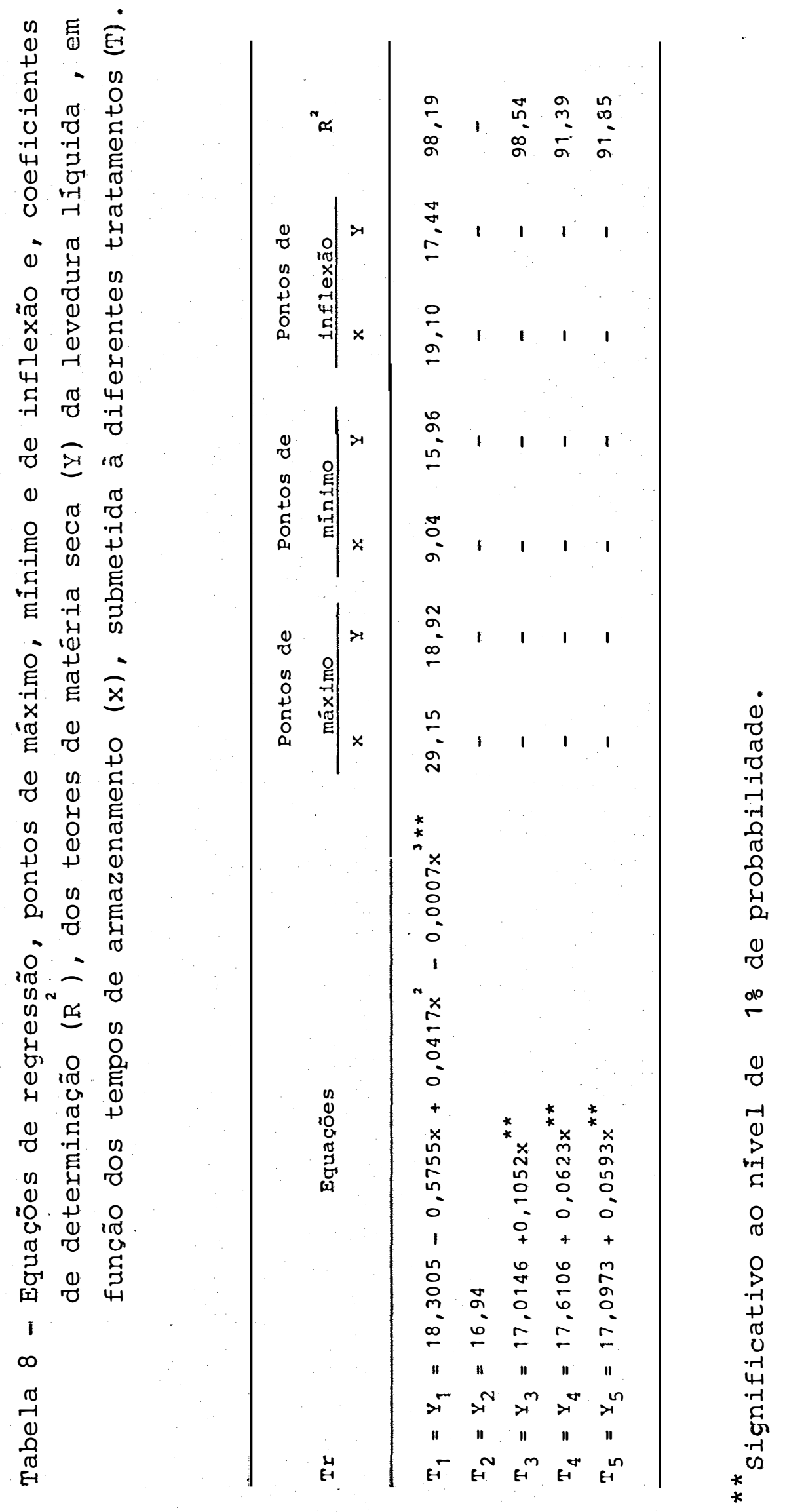




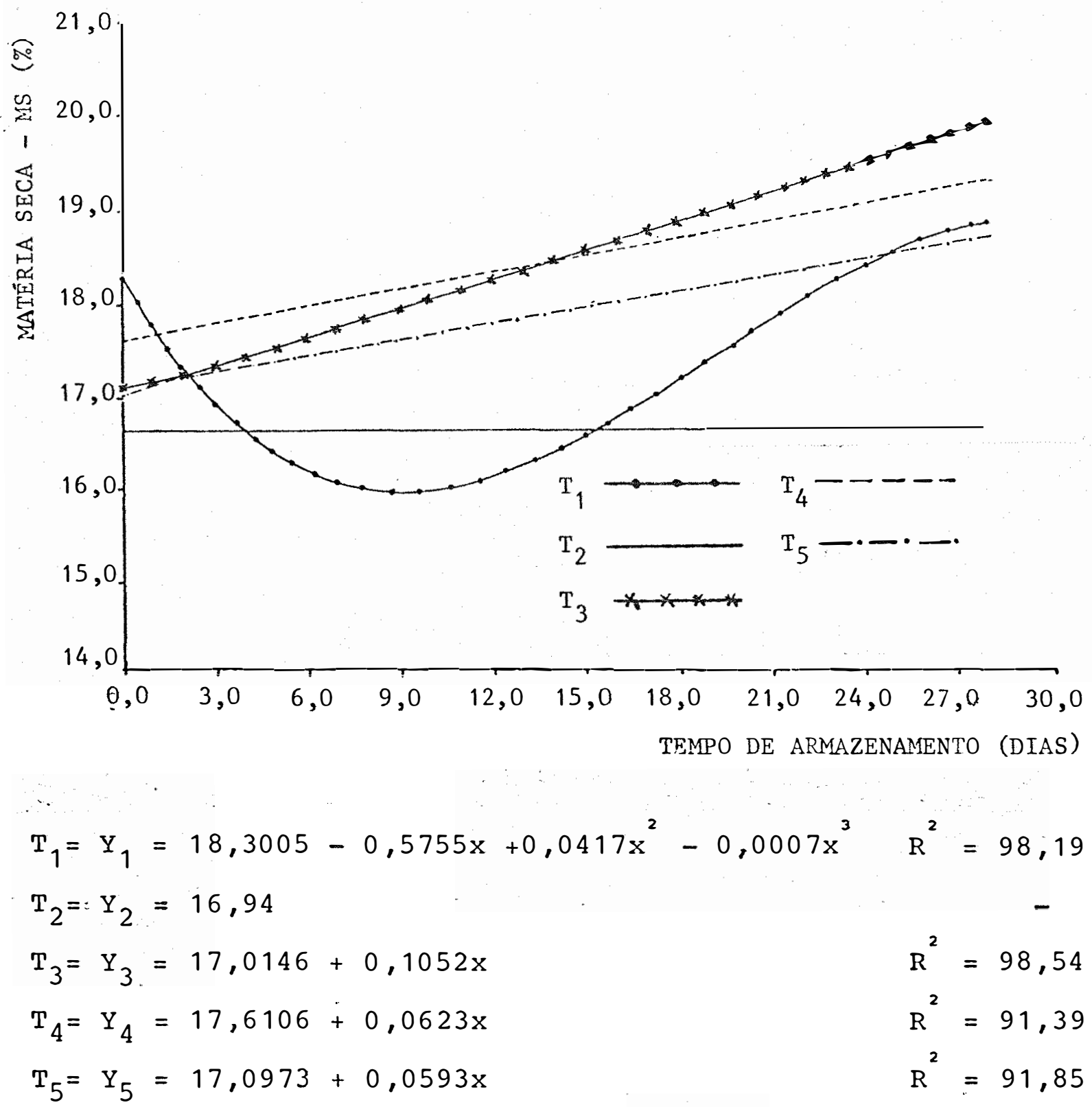

Figura 2 - Curvas, equações de regressão é coeficientes de de determinação $\left(\mathrm{R}^{2}\right)$ dos teores de matéria seca da le vedura (Y) em função do tempo de armazenamento (x), submetida a diferentes tratamentos (T). 
cou o teste de Tukey ao nivel de 5\% de probabilidade ( Tabela 6) ; havendo portanto um efeito semelhante dos tratamentos.Aos 28 dias detectaram-se diferenças significativas $(\mathrm{P}<0,01)$ en tre os tratamentos, evidenciando os tratamentos três e quatro, os quais alcançaram as maiores médias e diferiram apenas do tra tamento dois que apresentou a menor média; o que provavelmente se deve à sua condição de anaerobiose. As outras combinações não foram significativas.

\subsection{TEORES DE NITROGENIO TOTAL}

Os teores de nitrogênio total da levedura, subme tida aos diferentes tratamentos e tempos de armazenamento, são apresentados na Tabela 9 .

A análise de variância dos dados (Tabela 10) mostra diferenças significativas $(P<0,01)$ para todos os trata mentos dentro dos tempos de armazenamento. Para tempos de arma zenamento e interação "tratamento $x$ tempos de armazenamento" não houve diferenças estatísticas, embora o desdobramento dos graus de liberdade, tempos dentro do tratamento quatro tenha mostrado diferença significativa ao nível de 5\% de probabili dade.

As equações de regressão, juntamente com os pon tos de máximo, pontos de mínimo, ponto de inflexão e coefi. ciente de determinação, são apresentados na Tabela 11 e 


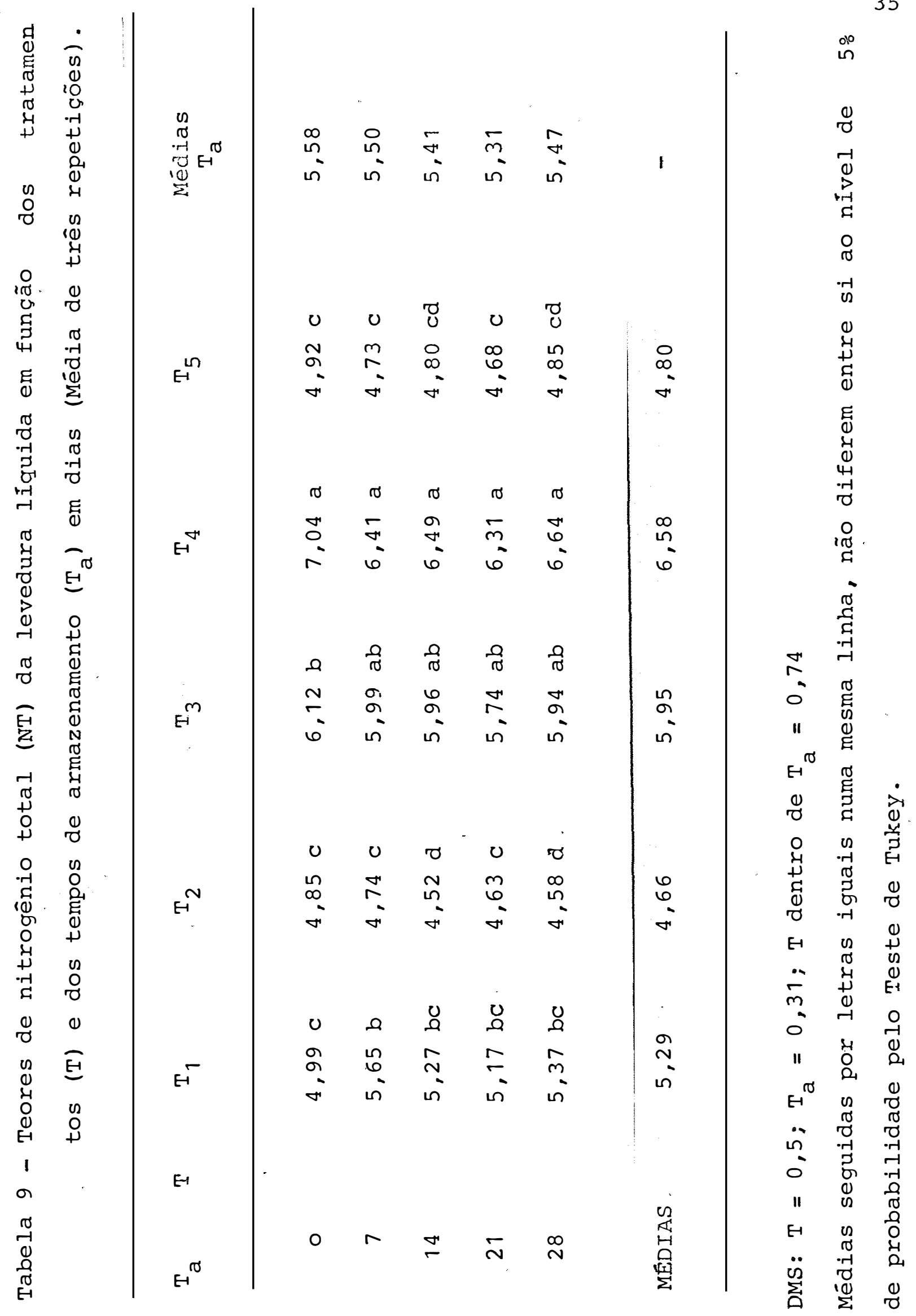


Tabela 10 - Análise de variância para os teores de nitrogênio total da levedura liquida em função dos tratamen tos $(T)$ e dos tempos de armazenamento ( $\left.\mathrm{T}_{\mathrm{a}}\right)$

\begin{tabular}{|c|c|c|}
\hline Fontes de variação & G.L. & QM \\
\hline Bloco & 2 & $0,22^{\mathrm{NS}}$ \\
\hline Tratamento (T) & 4 & $9,73^{\star \star}$ \\
\hline Residuo A) & 8 & 0.15 \\
\hline Parcela & 14 & \\
\hline Tempo de armazenamento $\left(\mathrm{T}_{\mathrm{a}}\right)$ & 4 & $0,16^{\mathrm{NS}}$ \\
\hline Interaçāo $\mathrm{T} \times \mathrm{T}_{\mathrm{a}}$ & 16 & $0.09^{\mathrm{NS}}$ \\
\hline $\mathrm{T}_{\mathrm{a}}$ dentro de $\mathrm{T}_{1}$ & 4 & $0.18^{\mathrm{NS}}$ \\
\hline $\mathrm{T}_{\mathrm{a}}$ dentro de $\mathrm{T}_{2}$ & 4 & $0.05^{\mathrm{NS}}$ \\
\hline $\mathrm{T}_{\mathrm{a}}$ dentro de $\mathrm{T}_{3}$ & 4 & $0.05^{\mathrm{NS}}$ \\
\hline $\mathrm{T}_{\mathrm{a}}$ dentro de $\mathrm{T}_{4}$ & 4 & $0,24^{*}$ \\
\hline $\mathrm{T}_{\mathrm{a}}$ dentro de $\mathrm{T}_{5}$ & 4 & $0,02^{\mathrm{NS}}$ \\
\hline$T$, dentro de $T_{0}$ & 4 & $2,81^{\star \star}$ \\
\hline $\mathrm{T}$ dentro de $\mathrm{T}_{7}$ & 4 & $1,69^{\star \star}$ \\
\hline $\mathrm{T}$ dentro de $\mathrm{T}_{14}$ & 4 & $1,99^{\star \star}$ \\
\hline $\mathrm{T}$ dentro de $\mathrm{T}_{21}$ & 4 & $1,54^{* *}$ \\
\hline $\mathrm{T}$ dentro de $\mathrm{T}_{28}$ & 4 & $2,08^{\star \star}$ \\
\hline Resíduo (B) & 40 & 0,08 \\
\hline Tolal & 74 & \\
\hline
\end{tabular}

IV Caso SATTERTHWAITE : GL T dentro de $\mathrm{T}_{\mathrm{a}}:=42$ QMR $\mathrm{T}$ dentro de $\mathrm{T}_{\mathrm{a}}=0,10$

C.V. : Resíduo $\mathrm{A}=7,26 \%$ Resíduo $\mathrm{B}=5,47 \%$ ** Significativo ao nível de $1 \%$ de probabilidade * Significativo ao nível de $5 \%$ de probabilidade $\mathrm{NS}_{\text {Não significatico. }}$ 


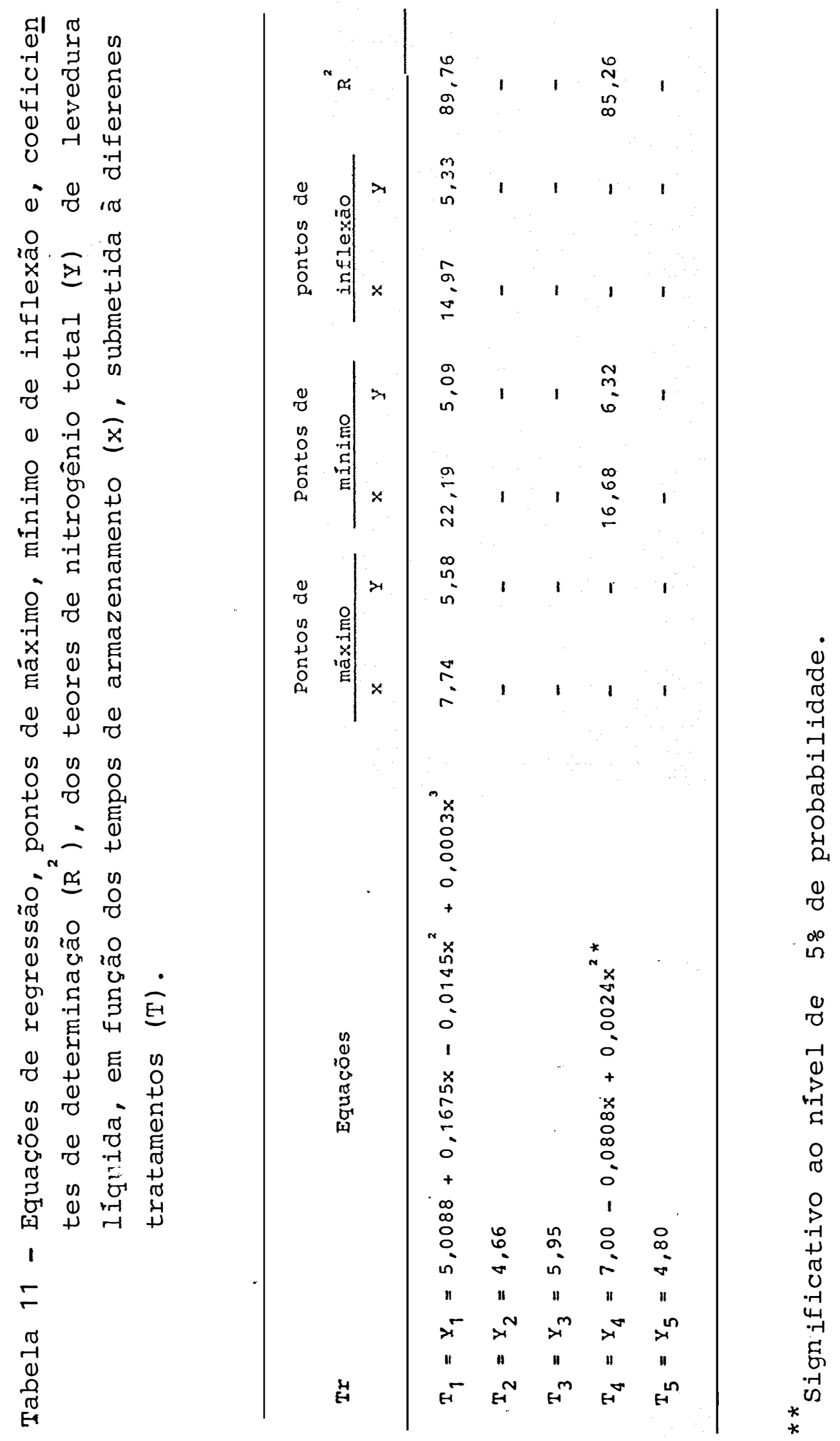


ilustrados na Figura 3, na qual observa-se que os teores de ni trogênio total do tratamento testemunha $\left(T_{1}\right)$ e do tratamento quatro seguiram as funções cúbica e quadrática, respectivamen te. O teor de nitrogênio do tratamento testemunha comportou-se de modo inverso ao teor de matéria seca. Este fato já era espe rado, pois o nitrogênio foi expresso em base de matéria seca estando em acordo com as observações de STECKLEY et alii (1979a). O efeito quadrático do tratamento quatro possivelmen te se deve à perda de nitrogênio amoniacal por volatilização, nos sete primeiros dias do ensaio, tendo em vista o forte odor amoniacal observado nestes dias e também à maior concentração do ma terial, no final do armazenamento, devido à perda de umidade.

Quanto aos tratamentos dois, três e cinco não houve efeito do tempo de armazenamento sobre o teor de nitrogê nio total.

O desdobramento dos graus de liberdade dos tra tamentos dentro de cada tempo de armazenamento (Tabela 10) mos tra que os tratamentos afetaram o teor de nitrogênio total da levedura em todos os tempos de armazenamento. Aplicando-se o teste de Tukey ao nível de $5 \%$ de probabilidade às médias dos tratamentos em cada tempo de armazenamento verifica-se (Tabela 9) que em todos os tempos de armazenamento o tratamento quatro apresentou o maior teor de nitrogênio total,porém diferiu do tratamento três apenas no tempo zero de armazenamento; este fa to se deve à adição de hidróxido de amônio aos referidos trata mentos. De um modo geral, em todos os tempos de armazenamento, 


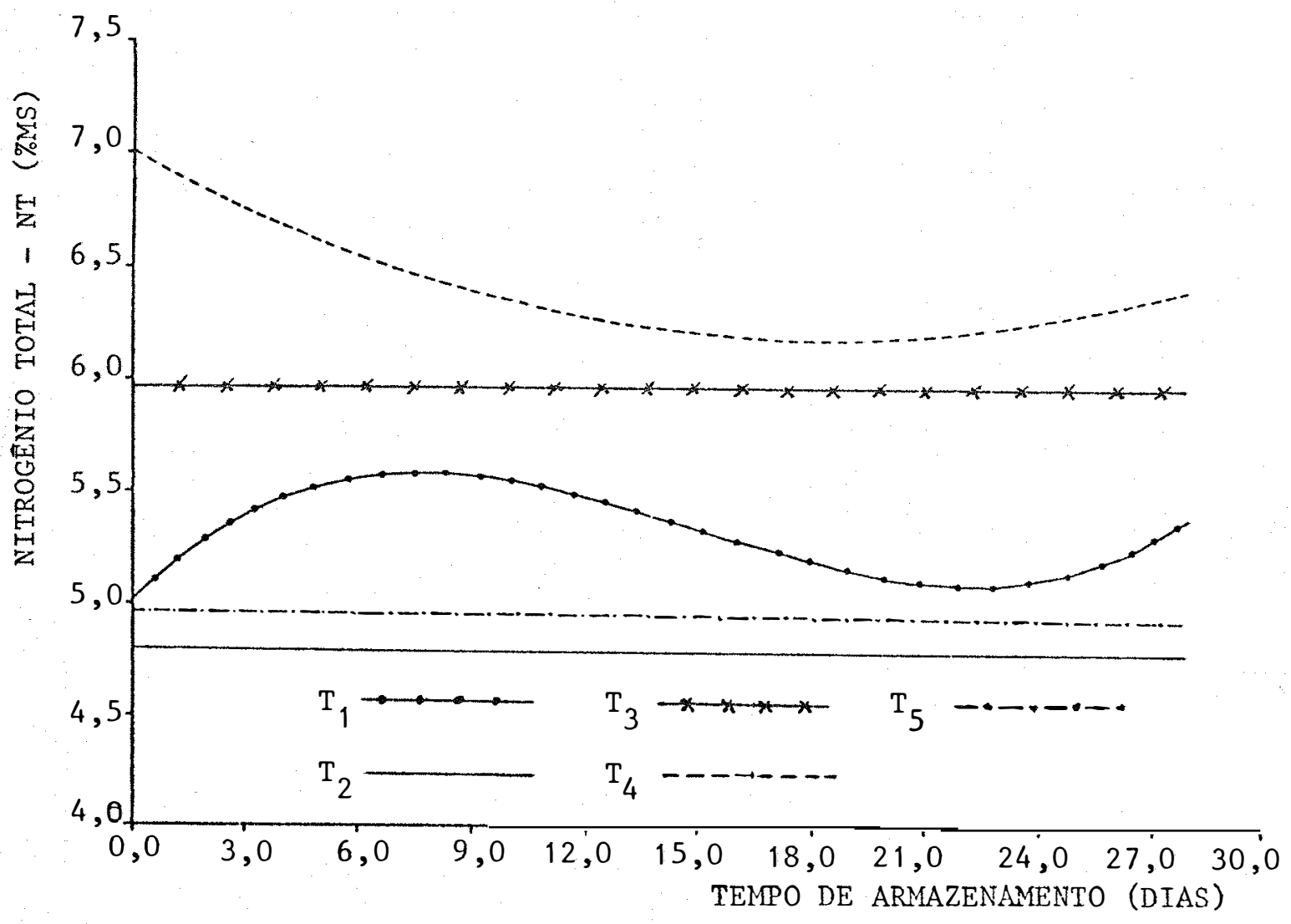

$$
\begin{array}{ll}
\mathrm{T}_{1}=\mathrm{Y}_{1}=5,0088+0,1675 \mathrm{x}-0,0145 \mathrm{x}^{2}+0,0003 \mathrm{x}^{3} \quad \mathrm{R}^{2}=89,76 \\
\mathrm{~T}_{2}=\mathrm{Y}_{2}=4,66 & - \\
\mathrm{T}_{3}=\mathrm{Y}_{3}=5,95 & \mathrm{R}^{2}=85,26 \\
\mathrm{~T}_{4}=\mathrm{Y}_{4}=7,0000-0,0808 \mathrm{x}+0,0024 \mathrm{x}^{2} & - \\
\mathrm{T}_{5}=\mathrm{Y}_{5}=4,80 &
\end{array}
$$

Figura 3 - Curvas, equações de regressão e coeficientes de de terminação $\left(R^{2}\right)$ dos teores de nitrogênio total da levedura $(Y)$ em função do tempo de armazenamento (x) , submetida à diferentes tratamentos (T). 
os tratamentos dois e cinco apresentaram os menores teores de nitrogênio e não diferiram entre si; o tratamento um apresen tou valores intermediários entre os demais tratamentos.

\subsection{TEORES DE NITROGẼNIO SOLÚVEL}

Na Tabela 12 estão apresentados os teores de ni trogênio solúvel da levedura, em função dos tratamentos e do tempo de armazenamento.

A análise de variância dos dados (Tabela 13), mostra diferenças significativas $(P<0,01)$ para tratamentos, tempos de armazenamento, interação "tratamento x tempo de arma zenamento" bem como no desdobramento dos graus de liberdade de tempos dentro do tratamento um (testemunha).

A solubilidade do nitrogênio no tratamento tes temunha, segue uma função cúbica, a qual é apresentada na Tabe la 14, juntamente com seus pontos de máximo, mínimo e inflexão e coeficiente de determinação conforme o ilustrado na Figura 4. Este acréscimo em solubilidade, pode ser devido à produção crescente de amônia (Figura 5). Resultados semelhantes foram observados poe STECKLEY et alii (1979a) ao estudarem o efeito da temperatura ou de aditivos químicos sobre a composição ni trogenada do lodo residual da fabricação de cerveja, ao longo de um período de armazenamento superior a 30 dias. Observaram também que a mudança em solubilidade estava relacionada com. 


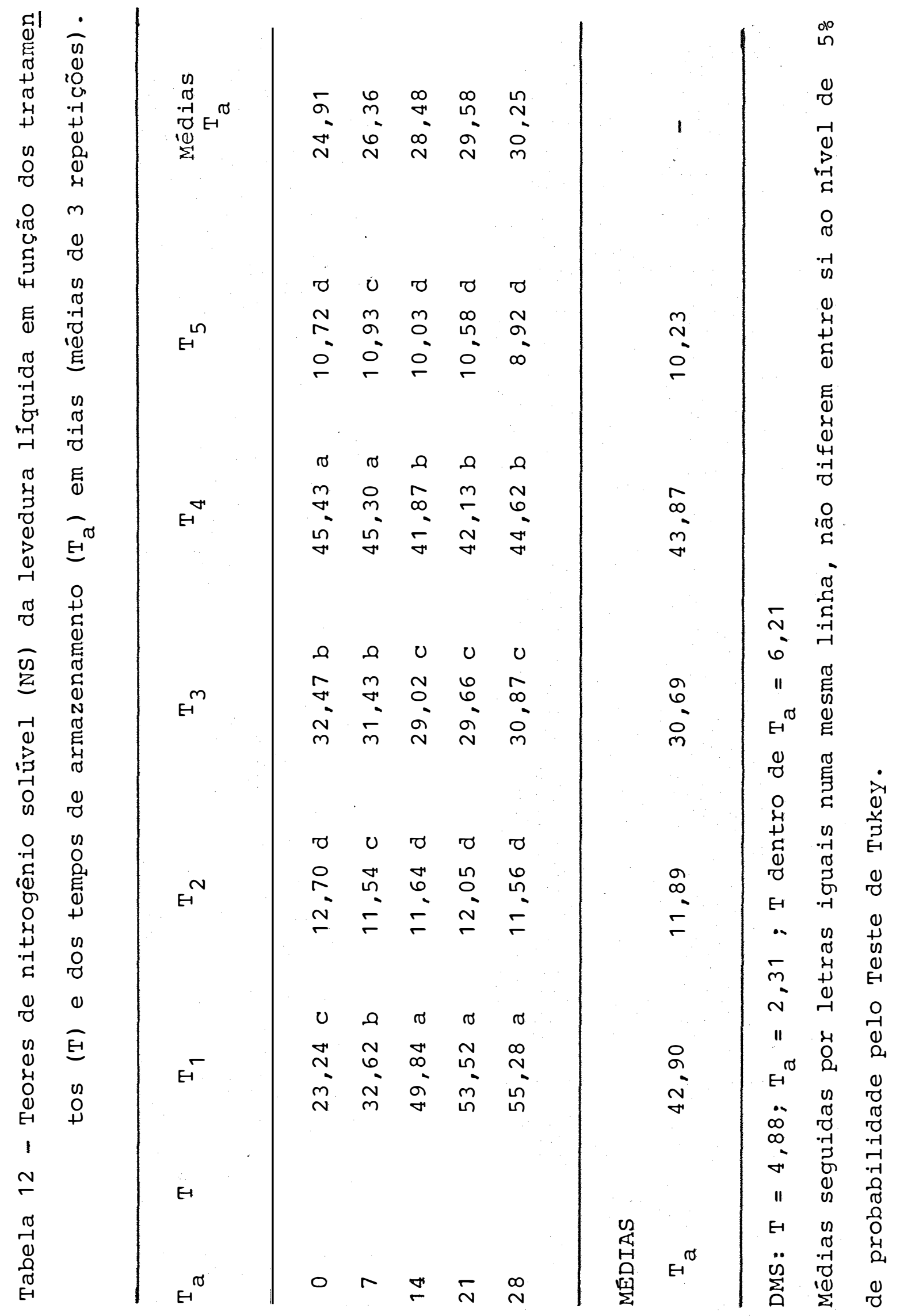


Tabela 13 - Análise de variância para os teores de nitrogênio solúvel da levedura líquida em função dos trata mentos $(T)$ e dos tempos de armazenamento $\left(T_{a}\right)$.

\begin{tabular}{|c|c|c|}
\hline Fontes de varıação & G.L. & $Q M$ \\
\hline Bloco & 2 & $27,59^{\mathrm{NS}}$ \\
\hline Tratamento $\left(T_{a}\right)$ & 8 & $3959,96^{\star *}$ \\
\hline Residuo (A) & 4 & 14,98 \\
\hline Parcela & 14 & \\
\hline Tempo de armazeriamento $\left(T_{a}\right)$ & 4 & $74,97^{* *}$ \\
\hline Interação $\mathrm{T} \times \mathrm{T}_{\mathrm{a}}$ & 16 & $136,79^{\star \star}$ \\
\hline$T_{a}$ dentro de $T_{1}$ & 4 & $604,70^{\star \star}$ \\
\hline$T_{a}$ dentro de $T_{2}$ & 4 & $0,73^{\mathrm{NS}}$ \\
\hline$T_{a}$ dentro de $T_{3}$ & 4 & $5,69^{\mathrm{NS}}$ \\
\hline $\mathrm{T}_{\mathrm{a}}$ dentro de $\mathrm{T}_{4}$ & 4 & $9,06^{\mathrm{NS}}$ \\
\hline$T_{a}$ dentro de $T_{5}$ & 4 & $1,96^{\mathrm{NS}}$ \\
\hline$T$ dentro de $T_{0}$ & 4 & $623,70^{\star \star}$ \\
\hline T dentro de $T_{7}$ & 4 & $660,94^{\star \star}$ \\
\hline$T$ dentro de $T_{14}$ & 4 & $944,79^{\star \star}$ \\
\hline$T$ dentro de $T_{21}$ & 4 & $1049,26^{\star *}$ \\
\hline$T$ dentro de $t_{28}$ & 4 & $1228,43^{\star \star}$ \\
\hline Resíduo (B) & 4 & 4,91 \\
\hline Total & 74 & \\
\hline
\end{tabular}

IV Caso SATteRthWAIte : GI $\mathrm{T}$ dentro de $\mathrm{T}_{\mathrm{a}}=32$ QMR T dentro de $\mathrm{T}_{\mathrm{a}}=6,92$

C.V. : Residuo $A=13,86 \%$ Residuo $B=7,94 \%$

** Significativo ao nivel de $1 \%$ de probabilidade ${ }^{N S}$ Não significativo. 


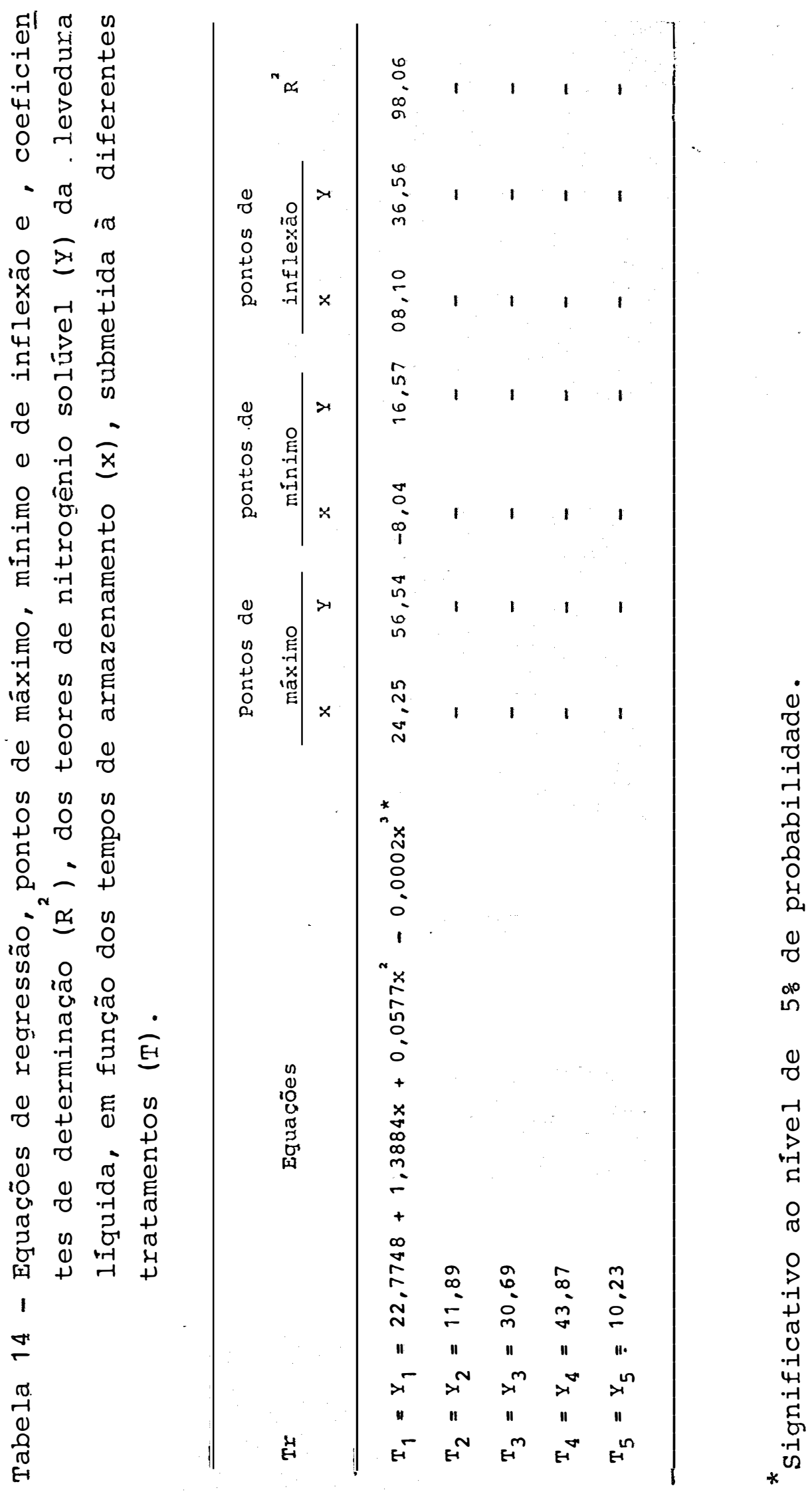




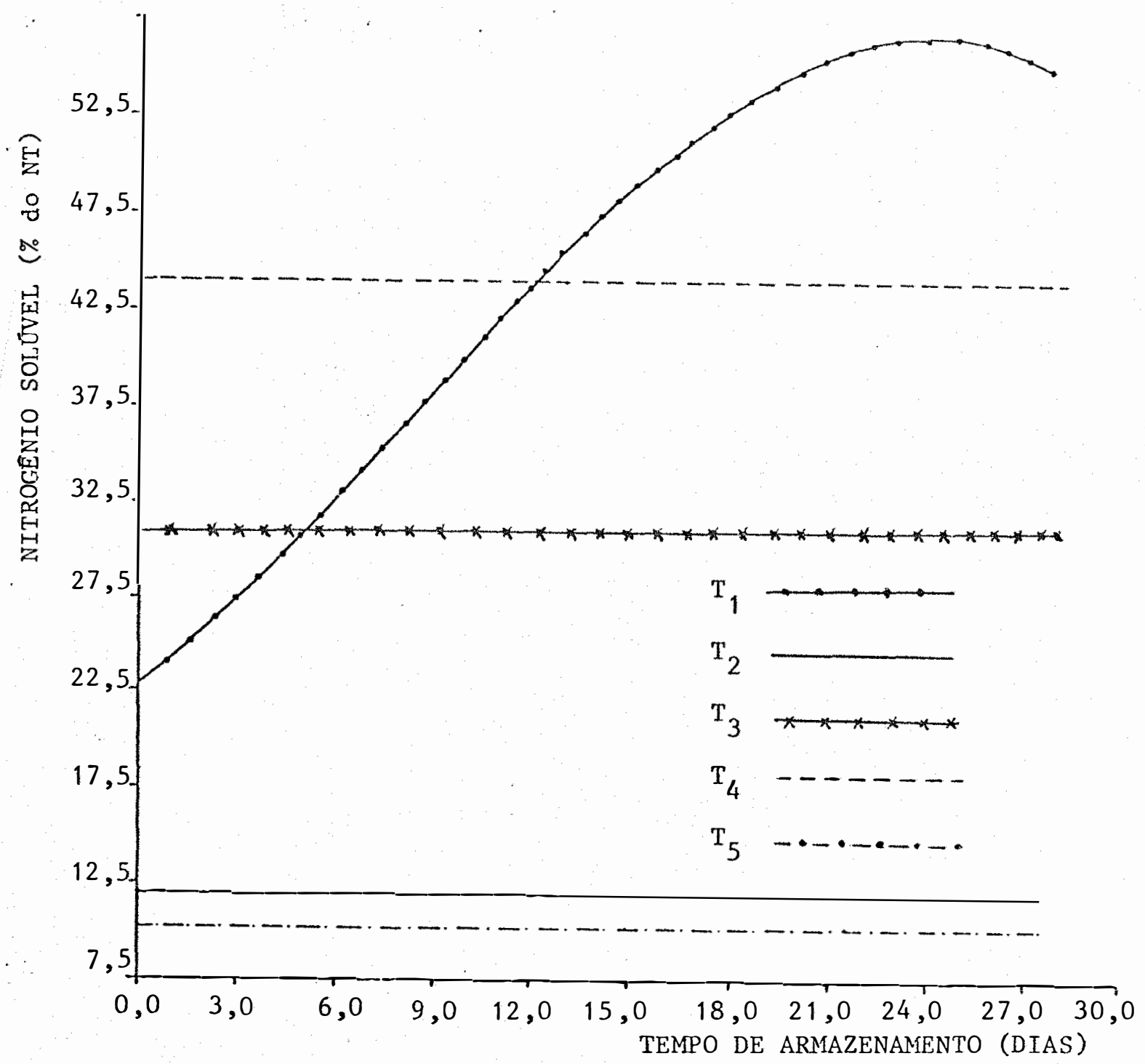

$$
\begin{aligned}
& \mathrm{T}_{1}=\mathrm{Y}_{1}=22,7748+1,3884 \mathrm{x}+0,0577 \mathrm{x}^{2}-0,0002 \mathrm{x}^{3} \cdot \mathrm{R}^{2}=98,06 \\
& \mathrm{~T}_{2}=\mathrm{Y}_{2}=11,89 \\
& \mathrm{~T}_{3}=\mathrm{Y}_{3}=30,69 \\
& \mathrm{~T}_{4}=\mathrm{Y}_{4}=43,87 \\
& \mathrm{~T}_{5}=\mathrm{Y}_{5}=10,23
\end{aligned}
$$

Figura 4 - Curvas, equações de regressão e coeficiente de detèr minação $\left(\mathrm{R}^{2}\right)$ dos teores de nitrogênio solúvel da le vedura (Y) em função do tempo de armazenamento (x) , submetida a diferentes tratamentos $(T)$. 


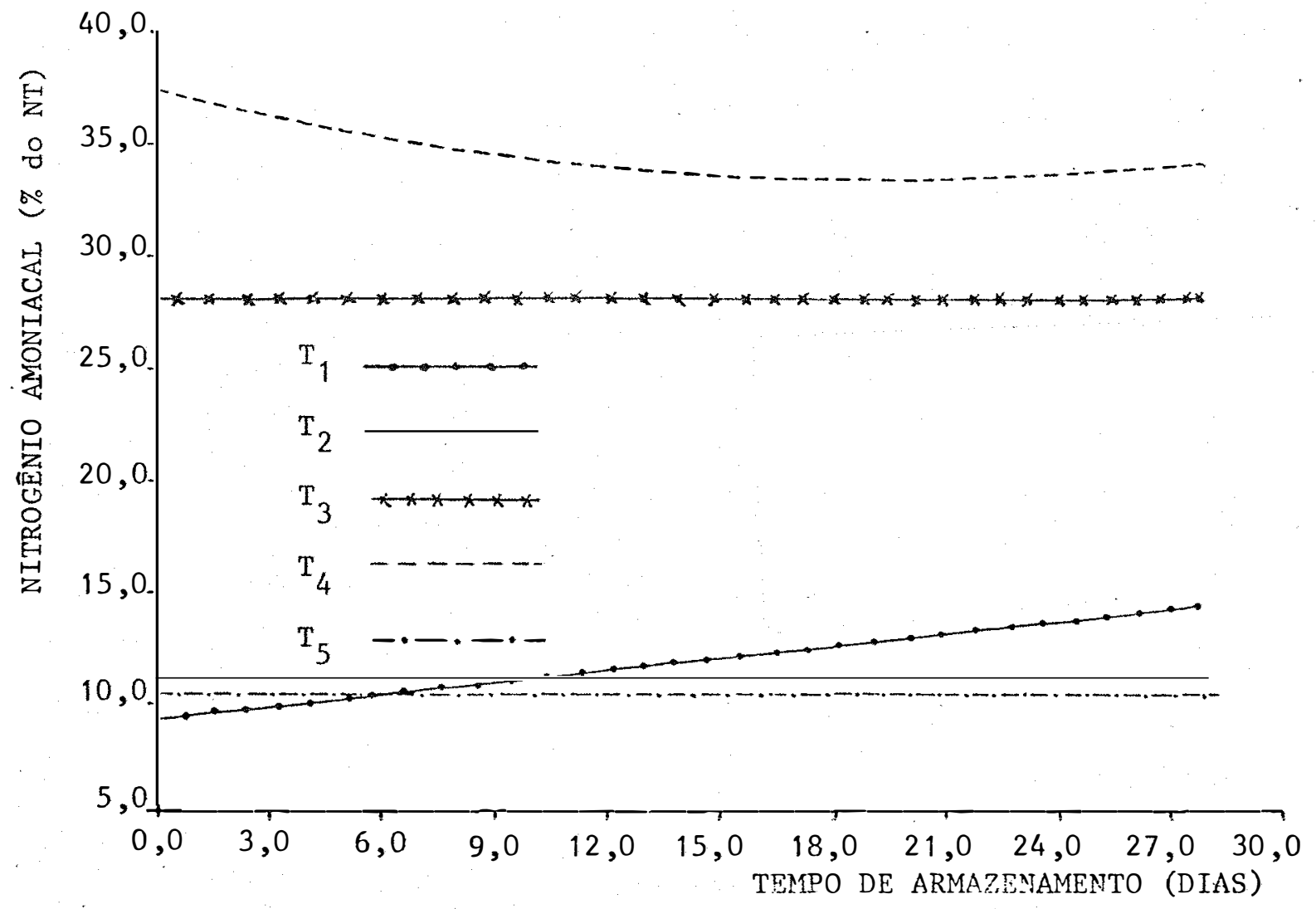

$$
\begin{array}{ll}
\mathrm{T}_{1}=\mathrm{Y}_{1}=9,2933+0,1833 \mathrm{x} & \mathrm{R}^{2}=94,95 \\
\mathrm{~T}_{2}=\mathrm{Y}_{2}=10,60 & \\
\mathrm{~T}_{3}=\mathrm{Y}_{3}=28,11 & \mathrm{R}^{2}=92,22 \\
\mathrm{~T}_{4}=\mathrm{Y}_{4}=37,3823-0,4032 \mathrm{x}+0,0104 \mathrm{x}^{2} & \\
\mathrm{~T}_{5}=\mathrm{Y}_{5}=10,13 &
\end{array}
$$

Figura 5 - Curvas, equações de rệressão e coeficientes de de terminação $\left(\mathrm{R}^{2}\right)$ dos teores de nitrogênio amoniacal da levedura (Y) em função do tempo de armazenamento (x), subrietida a diferentes tratamentos ( $T$ ). 
atividade proteolitica, diminuição da integridade celular e ex travasamento de constituintes nitrogenados para fora da célula. Considerando-se o tratamento testemunha, os teo res de nitrogênio amoniacal encontrados neste trabalho (Tabela 15) superam em até 50\% aqueles observados por STECKLEY et alii (1979a). Esta diferença provavelmente é devido ao tipo de ma terial estudado e às condições experimentais. Todavia BECKER (1961) salienta que um teor de amônia acima do normal indica uma decomposição bacteriana da proteína.

A solubilidade do nitrogênio nos demais trata mentos não se modificou ao longo dos 28 dias de armazenamento (Tabela 13). Porém verifica-se que o tratamento com vapor redu ziu a solubilidade do nitrogênio; isto pode ser observado com parando-se os valores médios atingidos pelos tratamentos dois e cinco com o testemunha, no tempo "zero" de armazenamento (Ta bela 12).

Os valores mais altos observados para os trata mentos três e quatro são devidos à aplicação de hidróxido de amônio.

O desdobramento dos graus de liberdade dos tra tamentos dentro de cada tempo de armazenamento (Tabela 13) mos tra efeito significativo dos tratamentos em todos os tempos de armazenamento.

Aplicando-e o teste Tukey às médias dos trata mentos em cada tempo de armazenamento (Tabela 12), verifica-se que no tempo "zero" o tratamento quatro apresentou o maior te 


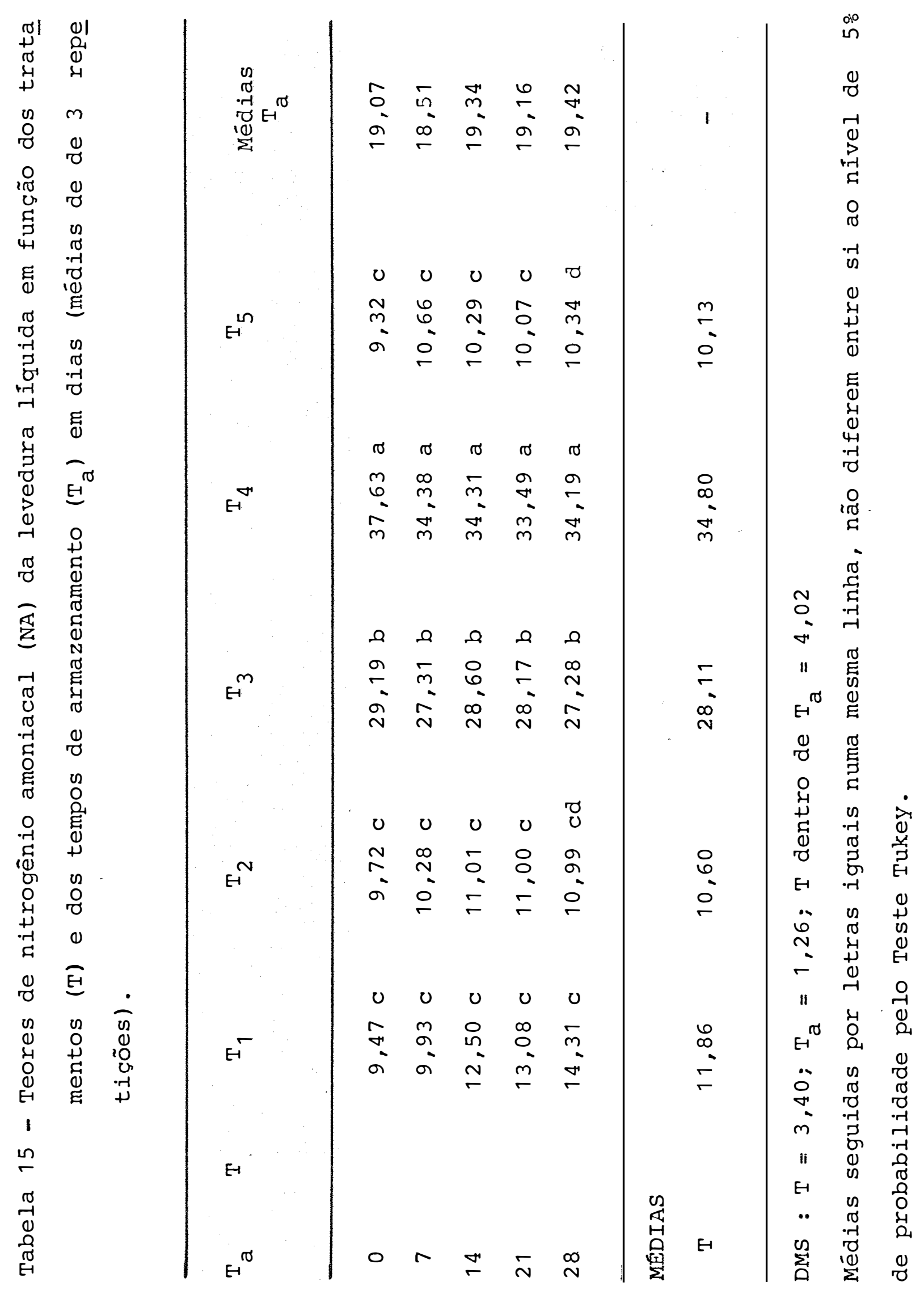


or de nitrogênio solúvel, superando a todos os outros tratamentos; o tratamento três, embora tenha apresentado valores inferiores ao quatro, também superou os demais tratamentós. Este fato de ve-se à adição de diferentes doses de hidróxido de amônio aos tratamentos três e quatro. O tratamento um (testemunha) também diferiu dos demais tratamentos, sendo inferior ao três e qua tro e superior ao dois e cinco, os quais apresentaram os meno res teores de nitrogênio solúvel e não diferiram entre si.Obser va-se portanto que o tratamento com vapor reduziu em aproxima damente $50 \%$ a solubilidade do nitrogênio da levedura. Aos sete dias de armazenamento os tratamentos três e quatro comportaram-. se de maneira idêntica ao tempo "zero", porém no tratamento um a solubilidade aumentou e não diferiu do. tratamento três $(P<0,05)$. Os tratamentos dois e cinco foram iguais entre si, porém infe riores aos demais. Para os tempos de 14, 21 e 28 dias de armaze namento, o tratamento um apresentou os maiores teores de nitro gênio solúvel e diferiu $(p<0,05)$ de todos os outros tratamen tos, indicando uma provável degradação das proteínas da levedu ra. Os tratamentos três e quatro,embora diferentes entre si, superaram os tratamentos dois e cinco, que foram estatisticamen te iguais.

\subsection{TEORES DE NITROGENIO AMONIACAL}


líquida, em função dos tratamentos e dos tempos de armazenamen to, são apresentados na Tabela 15 .

A análise de variância (Tabela 16) mostra dife renças significativas $(\mathrm{P}<0,01)$ para tratamentos, interação "tra tamento $\mathrm{x}$ tempos de armazenamento" e para o desdobramento dos graus de liberdade, tempos de armazenamento dentro do tratamen to um e quatro.

As equações de regressão e coeficientes de de terminação são apresentados na Tabela 17 e ilustrados na Figura 5. Verifica-se que o teor de nitrogênio amoniacal aumentou li nearmente para o tratamento testemunha; isto comprova a hipótese anteriormente proposta, na qual se considerava que $\circ$ aumen to na solubilidade do nitrogênio era devido à produção crescen te de nitrogênio amoniacal pela levedura, devido à degradação bacteriana de suas proteínas,e esta de acordo com as observa ções de STECKLEY et alii (1979a). Para o tratamento quatro a variação do teor de nitrogênio amoniacal segue uma função qua drática, sendo possivel as mesmas explicações dadas para o te or de nitrogênio total, o qual apresentou comportamento idênti co. Os tratamentos três e quatro apresentaram os maiores teo res de nitrogênio amoniacal, devido a adição do hidróxido de a mônio. Os tratamentos dois e cinco apresentaram os teores mais baixos, ou seja, aqueles que fazem parte da composição da leve dura (Tabela 15).

O desdobramento dos graus de liberdade dos tra tamentos dentro de cada tempo de armazenamento (Tabela 16), re 
Tabela 16 - Análise de variância para os teores de nitrogênio amoniacal da levedura líquida em função dos trata mentos $(T)$ e dos tempos de armazenamento $\left(T_{a}\right)$.

\begin{tabular}{|c|c|c|}
\hline Fontes de variação & G.L. & QM \\
\hline Bloco & 2 & 8,44 \\
\hline Tratamento $(T)$ & 4 & $1997.97^{* *}$ \\
\hline Residuo (A) & 8 & 7,29 \\
\hline Parcela & 14 & \\
\hline Tempo de armazenamento $\left(T_{a}\right)$ & 4 & $1,92^{\mathrm{NS}}$ \\
\hline Interação $\mathrm{T} \times \mathrm{T}_{\mathrm{a}}$ & 16 & $5,70^{\star \star}$ \\
\hline$T_{a}$ dentro de $T_{1}$ & 4 & $13,00^{\star \star}$ \\
\hline$T_{a}$ dentro de $T_{2}$ & 4 & $1,02^{\mathrm{NS}}$ \\
\hline $\mathrm{T}_{\mathrm{a}}$ dentro de $\mathrm{T}_{3}$ & 4 & $2.06^{\mathrm{NS}}$ \\
\hline $\mathrm{T}_{\mathrm{a}}$ dentro de $\mathrm{T}_{4}$ & 4 & $7,89^{\star \star}$ \\
\hline $\begin{array}{l}T_{a} \text { dentro de } T_{5} \\
T \text { dentro de } T_{0}\end{array}$ & $\begin{array}{l}4 \\
4\end{array}$ & $\begin{array}{r}0,75^{\mathrm{NS}} \\
541,34^{\star \star}\end{array}$ \\
\hline$T$ dentro de $T_{7}$ & 4 & $399,31^{* *}$ \\
\hline T dentro de $T_{14}$ & 4 & $380,86^{\star \star}$ \\
\hline$T$ dentro de $T_{21}$ & 4 & $354,59^{\star \star}$ \\
\hline$T$ dentro de $T_{28}$ & 4 & $344,67^{\star \star}$ \\
\hline Residuo (B) & 40 & 1,70 \\
\hline Total & 74 & \\
\hline
\end{tabular}

IV Caso SATTERTHWATE : GL $\mathrm{T}$ dentro de $\mathrm{T}_{\mathrm{a}}=26$ QMR $\mathrm{T}$ dentro de $\mathrm{T}_{\mathrm{a}}=2,82$

C.V. : Residuo $A=14,13 \% ;$ Residuo $B=6,84$ 응 ** Significativo ao nivel de $1 \%$ de probabilidade $\mathrm{NS}_{\text {Não significativo. }}$ 


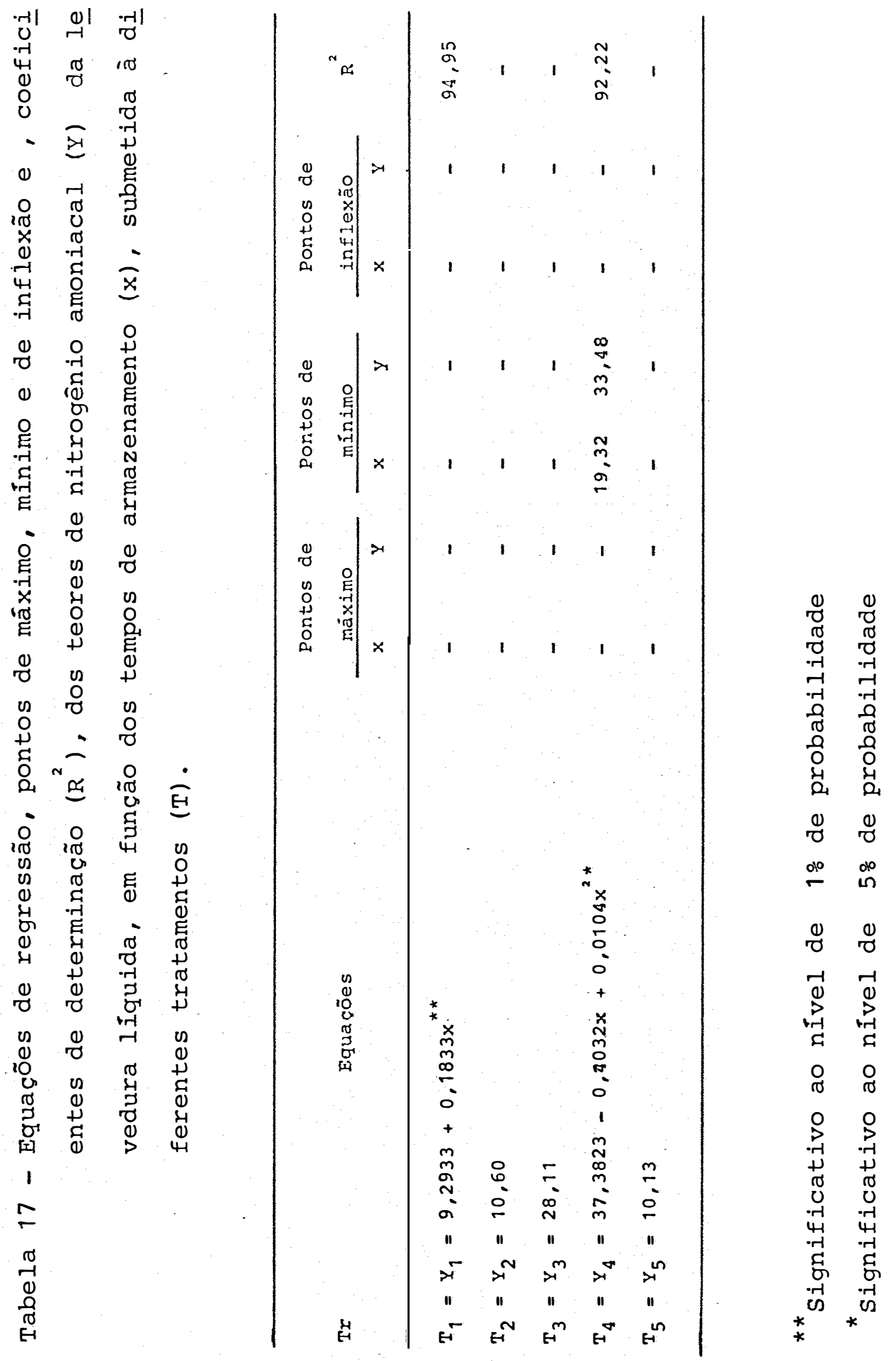


vela significância $(P<0,01)$ para os tratamentos em todos os tem pos de armazenamento. Através do Teste de Tukey aplicado aos dados da Tabela 15, verifica-se que em todos os tempos de arma zenamento o tratamento quatro apresentou os maiores teores de nitrogênio amoniacal, diferindo dos demais tratamentos $(P<0,05)$. o tratamento três foi superior $(P<0,05)$ aos tratamentos um, dois e cinco. Os maiores teores de nitrogênio amoniacal, encon trados para os tratamentos três e quatro, devem-sea adição do hidróxido de amônio aos mesmos. Os tratamentos un, dois e cinco a-presentaram os menores teores de nitrogênio amoniacal em todos os tem pos de armazenamento e não diferiram entre si. Embora aos 28 dias o tratamento cinco apresentou o menor teor e o tratamento um o maior'teor de nitrogênio amoniacal.

\subsection{TEORES DE NITROGENIO NÃO PROTÉICO}

Na Tabela 18 são apresentados os teores de ni trogênio não protéico da levedura submetida a diversos trata mentos e vários tempos de armazenamentos.

A análise de variância (Tabela 19) mostra dife renças significativas $(P<0,01)$, para tratamentos, tempos de armazenamento, bem como para sua interação. o desdobramento dos graus de liberdade, tempos dentro de tratamento,mostra sig nificância $(P<0,01)$ apenas para o tratamento um (testemunha).

As 'equações de regressão, juntamente com os res 


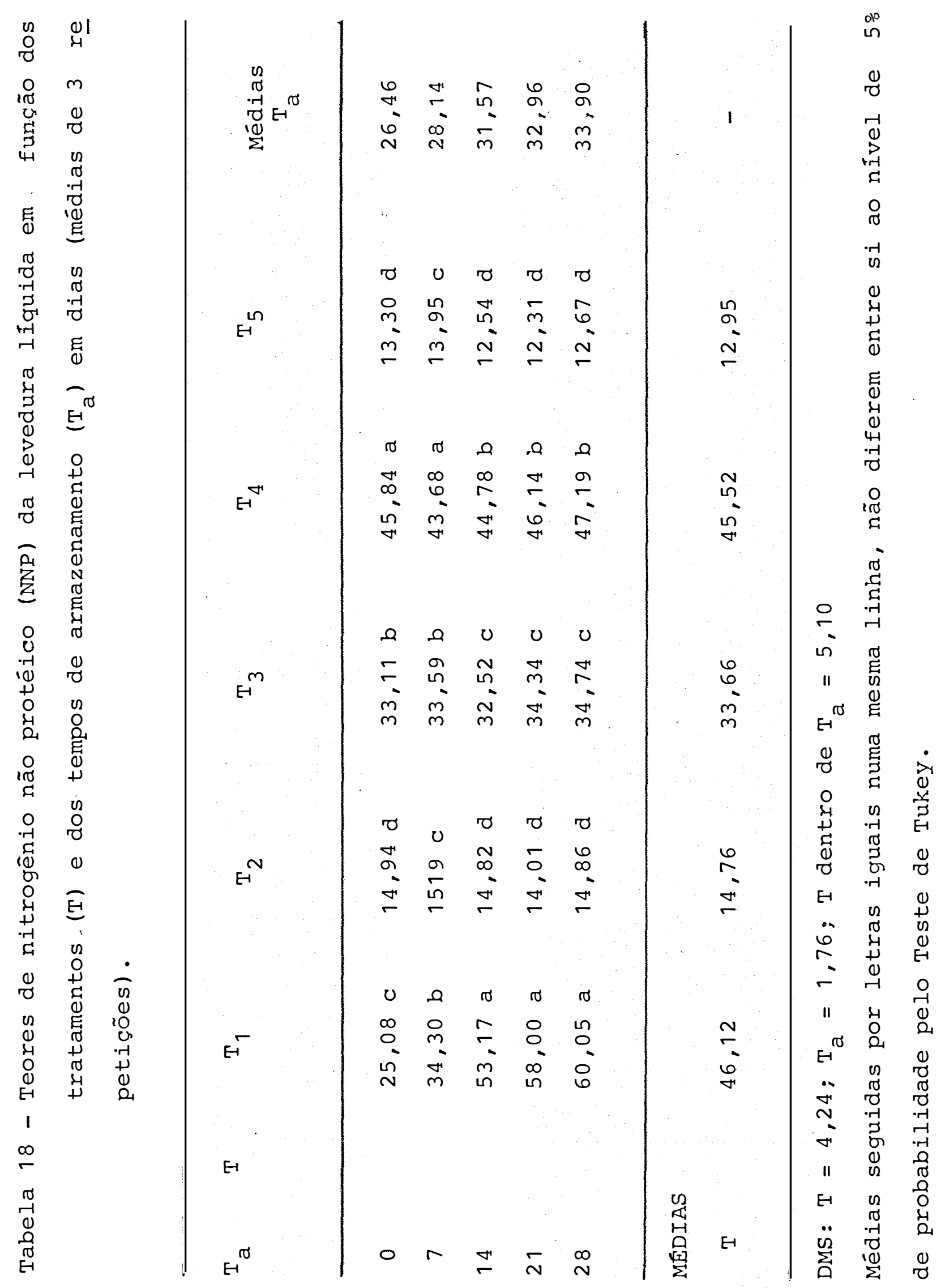


Tabela 19 - Análise de variância para os teores de nitrogênio não protéico da levedura liquida em função dos tra tamentos $(T)$ e dos tempos de armazenamento $\left(T_{a}\right)$.

\begin{tabular}{|c|c|c|}
\hline Fontes de variação & G.L. & QM \\
\hline Bloco & 2 & $56,80^{*}$ \\
\hline Tratamento (T) & 4 & $3881,47^{\star \star}$ \\
\hline Residuo (A) & 8 & 11,31 \\
\hline Parcela & 14 & \\
\hline Tempo de armazenamento $\left(T_{a}\right)$ & 4 & $152,31^{\star \star}$ \\
\hline Interação $T \times T_{a}$ & 16 & $145,71^{\star \star}$ \\
\hline $\mathrm{T}_{\mathrm{a}}$ dentro de $\mathrm{T}_{1}$ & 4 & $725,40^{\star *}$ \\
\hline $\mathrm{T}_{\mathrm{a}}$ dentro de $\mathrm{T}_{2}$ & 4 & $0,59^{\mathrm{NS}}$ \\
\hline $\mathrm{T}_{\mathrm{a}}$ dentro de $\mathrm{T}_{3}$ & 4 & $2,42^{\mathrm{NS}}$ \\
\hline $\mathrm{T}_{\mathrm{a}}$ dentro de $\mathrm{T}_{4}$ & 4 & $5,41^{\mathrm{NS}}$ \\
\hline $\mathrm{T}_{\mathrm{a}}$ dentro de $\mathrm{T}_{5}$ & 4 & $1,33^{\mathrm{NS}}$ \\
\hline $\mathrm{T}$ dentro de $\mathrm{T}_{0}$ & 4 & $545,60^{* \star}$ \\
\hline $\mathrm{T}$ dentro de $\mathrm{T}_{7}$ & 4 & $508,47^{* *}$ \\
\hline $\mathrm{T}$ dentro de $\mathrm{T}_{14}$ & 4 & $963,41^{\star *}$ \\
\hline $\mathrm{T}$ dentro de $\mathrm{T}_{21}$ & 4 & $1191,16^{\star \star}$ \\
\hline $\mathrm{T}$ dentro de $\mathrm{T}_{28}$ & 4 & $1255,65^{\star \star}$ \\
\hline Resíduo (B) & 40 & 2,87 \\
\hline Total & 74 & \\
\hline
\end{tabular}

IV Caso SAtTeRthwaite : GL T dentro de $\mathrm{T}_{\mathrm{a}}=27$ QMR $\mathrm{T}$ dentro de $\mathrm{T}_{\mathrm{a}}=4,56$

C.V. : Residuo $A=10,99 \% ;$ Residuo $B=5,54 \%$ ** Significativo ao nivel de $1 \%$ de probabilidade * Significativo ao nivel de 5\% de probabilidade $\mathrm{NS}_{\text {Não }}$ significativo: 
pectivos pontos de máximo, de mínimo e de inflexão e, coeficí ente de determinação, são apresentados na Tabela 20 e ilustra dos na Figura 6.

O teor de nitrogênio não protéico do tratamento testemunha segue uma função do terceiro grau (Figura 6). Este resultado provavelmente se deve à produção de compostos nitro genados não protéicos, tais como, amônia, peptídeos e aminoácí dos livres, devido à decomposição bacteriana das proteinas da levedura. Os resultados de STECKLEY et alii (1979a), embora ex pressos em proteina verdadeira, são semelhantes aos observados neste trabalho. Os tratamentos dois e cinco apresentaram os me nores teores de nitrogênio não protéico, sendo inclusive infe riores aos 25\% citados por ROSE e HARRISSON (1970) e KIHLBERG (1972). Os tratamentos três e quatro apresentaram os maiores teores devido a adição do hidróxido de amônio.

O desdobramento dos graus de liberdade dos tra tamentos dentro de cada tempo de armazenamento (Tabela 19) mos tra efeito significativo para tratamento $(P<0,01)$ em todos os tempos de armazenamento.

O Teste de Tukey aplicado aos dados da Tabela 18 aponta os tratamentos três e quatro com os maiores teores de nitrogênio não protéico, porém foram diferentes entre si e os demais tratamentos, no tempo zero de armazenamento. Os tra tamentos dois e cinco apresentaram os menores teores e foram estatisticamente iguais entre si, em todos os tempos de armaze namento. No tempo zero esperava-se igualdade estatistica para 

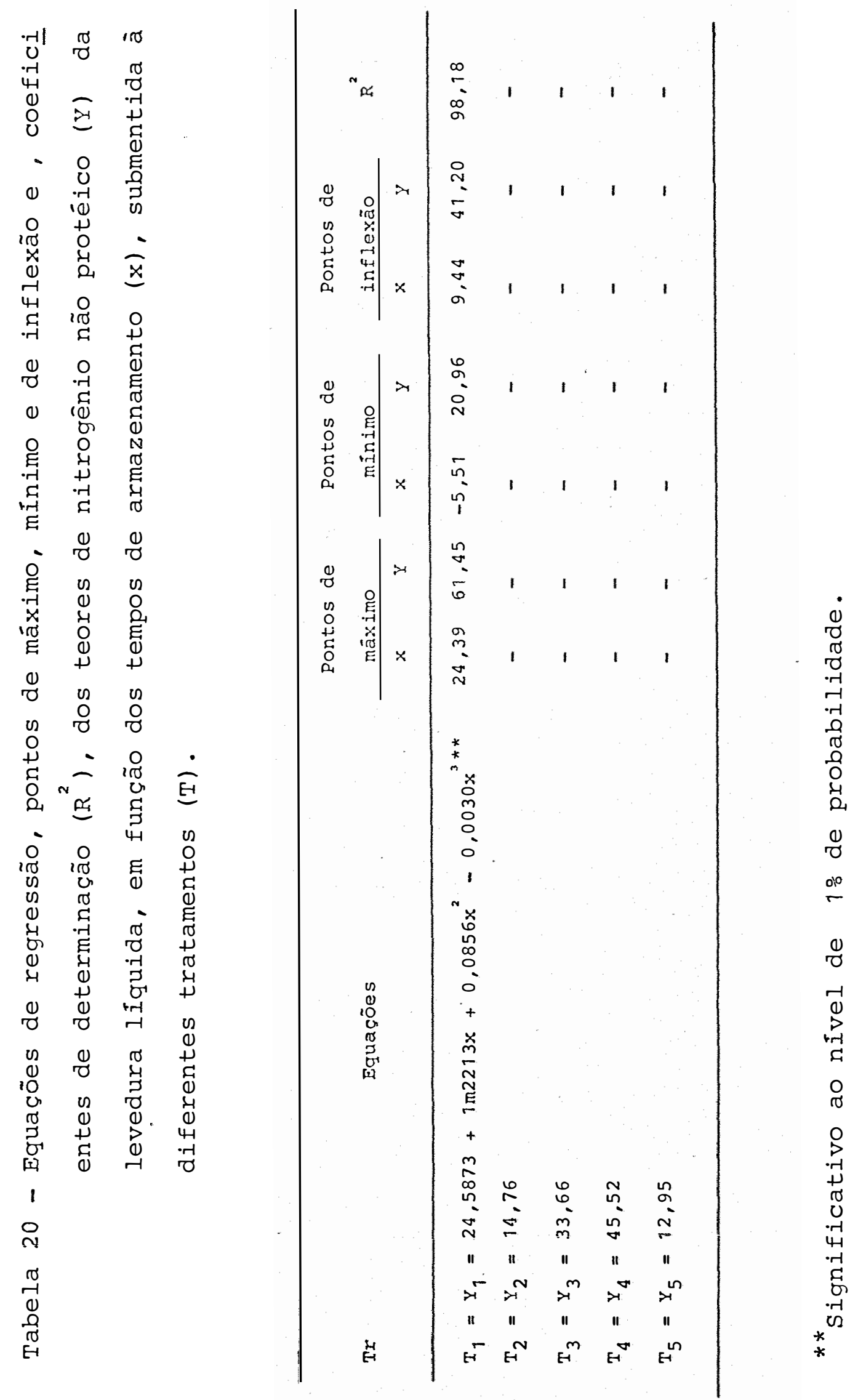


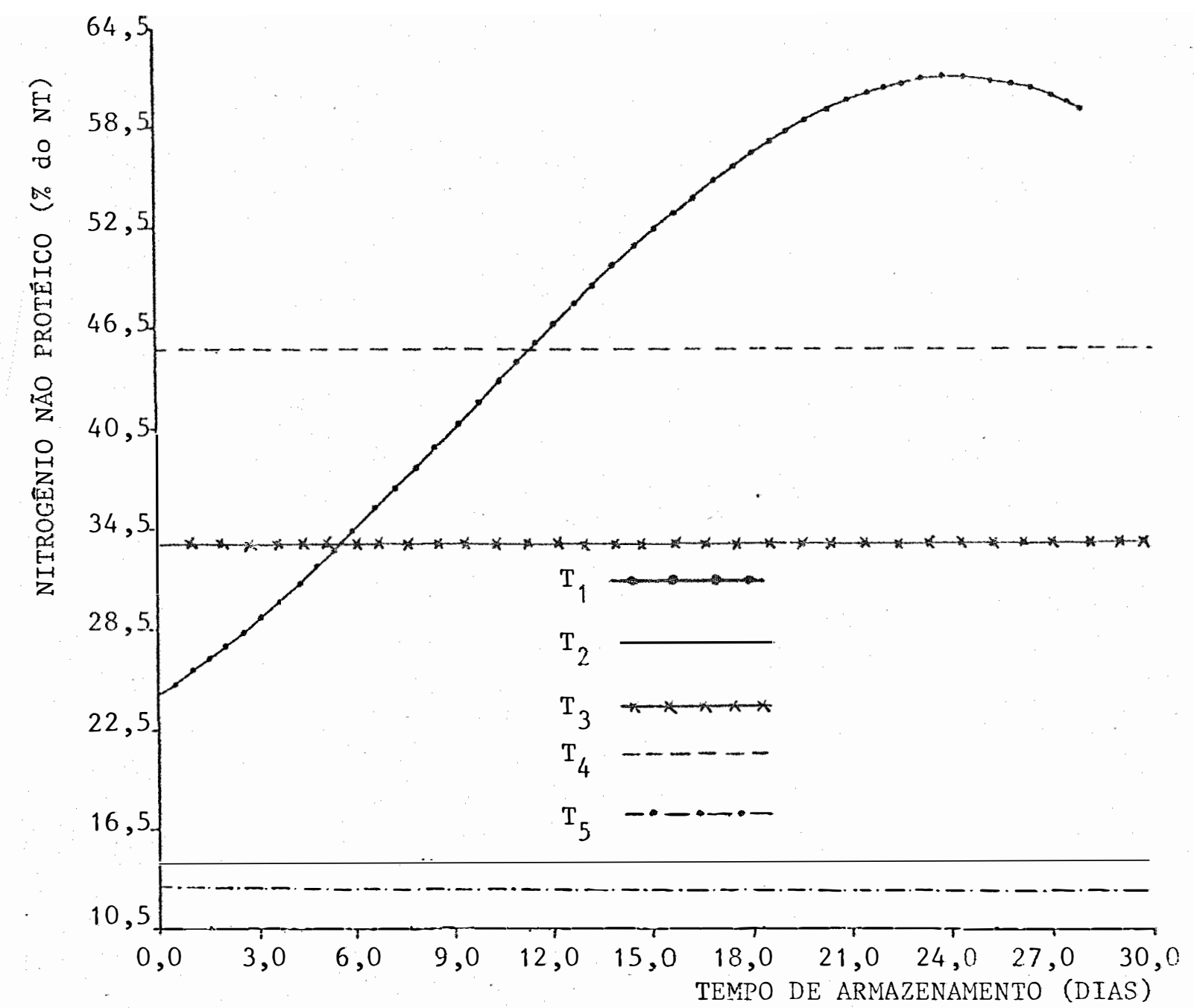

$$
\begin{aligned}
& \mathrm{T}_{1}=\mathrm{Y}_{\uparrow}=24,5873+1,2213 \mathrm{x}+0,0856 \mathrm{x}^{2}-0,0003 \mathrm{x}^{3 * *} \quad \mathrm{R}^{2}=98,19 \\
& \mathrm{~T}_{1}=\mathrm{Y}_{2}=14,76 \\
& \mathrm{~T}_{3}=\mathrm{Y}_{3}=33,66 \\
& \mathrm{~T}_{4}=\mathrm{Y}_{4}=45,52 \\
& \mathrm{~T}_{5}=\mathrm{Y}_{5}=12,95
\end{aligned}
$$

Figura 6 - Curvas, equações de regressão e coeficientes de de terminação $\left(\mathrm{R}^{2}\right)$ dos teores de nitrogênio não protéi co da levedura (Y) em função dos tempos de armazena mento (x), submetida a diferentes tratamentos (T). 
os tratarnentos um, dois e cinco. Entretanto, o tratamento um foi superior. Isto possivelınente se deve à algum processo degradativo que tenha ocorrido no material não tratado, mesmo que armazenado a baixa temreratura $\left(-20^{\circ} \mathrm{C}\right)$, condição em que as amostras de todos os tratamentos permaneceram durante vários meses, antes de serem analisadas.

Aos 7 dias de armazenamento os tratamentos apresentaram valores senelhantes à aqueles do tempo zero, exceto o tratamento um, que apresentou um aumento de 50\% no teor de nitrogênio não proteíco. A par tir dos 14 dias de armazenamento, o tratamento um superou os demais, quanto ao teor de nitrogênio não protéico (Tabela 18), indicando que houve degradação das proteínas da levedura não tratada.

\subsection{VALORES DO PH}

Os valores médios de $\mathrm{pH}$ da levedura, observados nos diversos tratamentos em cada tempo de armazenamento, são apresentados na Tabela 21 .

A anālise de variância (Tabela 22) mostra dife renças significativas $(\mathrm{P}<0,01)$ para tratamentos, tempo de arma zenamento, bem como para suas interações. O desdobramento dos graus de liberdade, tempos de armazenamento dentro de tratamen to mostra diferenças significativas $(\mathrm{P}<0,01)$ para os tratamen tos dois, três e. quatro.

As equações de regressão, juntamente com os res pectivos pontos de máximo, mínimo, inflexão e coeficientes de determinação, são apresentados na Tabela 23, e ilustrados na Figura 7 . 


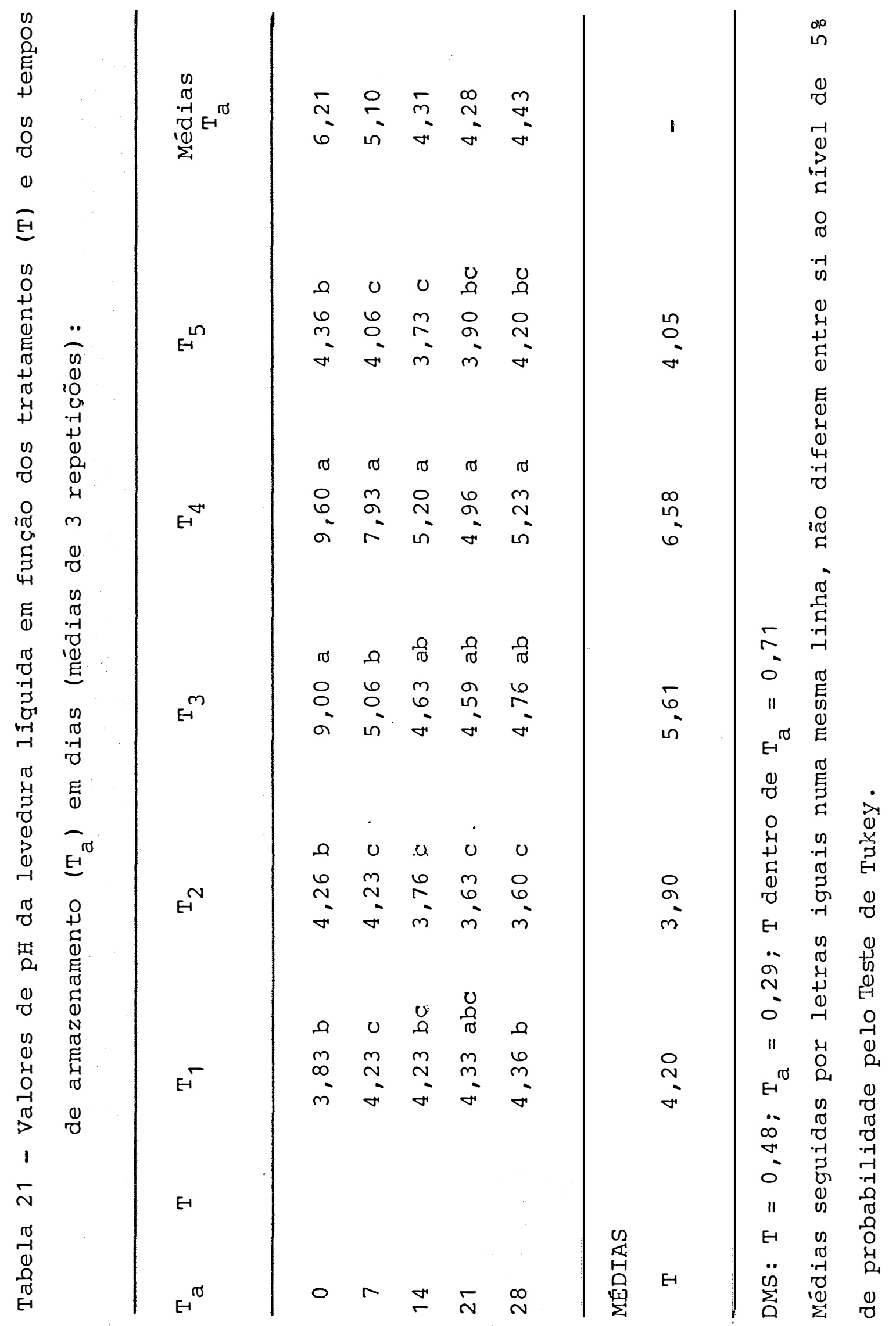


Tabela 22 - Análise de variância para os valores de pH da levedura líquida em função dos tratamentos (T) e dos tempos de armazenamento $\left(\mathrm{T}_{\mathrm{a}}\right)$.

\begin{tabular}{|c|c|c|}
\hline Fontes de variação & G.I. & QM \\
\hline Bloco & 2 & $0,30^{\mathrm{NS}}$ \\
\hline Tratamento $(T)$ & 4 & $20,83^{\star \star}$ \\
\hline Residuo (A) & 8 & 0,15 \\
\hline Parcela & 14 & \\
\hline Tempo de armazenamento $\left(\mathrm{T}_{\mathrm{a}}\right)$ & 4 & $10,13^{\text {* }}$ \\
\hline Interaçāo $T \times T_{a}$ & 16 & $3,58^{* \star}$ \\
\hline $\mathrm{T}_{\mathrm{a}}$ dentro de $\mathrm{T}_{1}$ & 4 & $0,13^{\mathrm{NS}}$ \\
\hline $\mathrm{T}_{\mathrm{a}}^{\mathrm{d}}$ dentro de $\mathrm{T}_{2}$ & 4 & $0,31^{* \star}$ \\
\hline $\mathrm{T}_{\mathrm{a}}^{\mathrm{d}}$ dentro de $\mathrm{T}_{3}$ & 4 & $10,85^{*}$ \\
\hline $\mathrm{T}_{\mathrm{a}}^{\mathrm{d}}$ dentro de $\mathrm{T}_{4}$ & 4 & $12,95^{* *}$ \\
\hline$T_{a}$ dentro de $T_{5}$ & 4 & $0,18^{\mathrm{NS}}$ \\
\hline $\mathrm{T}$ dentro de $\mathrm{T}_{0}$ & 4 & $24,07^{\star \star}$ \\
\hline $\mathrm{T}$ dentro de $\mathrm{T}_{7}$ & 4 & $7,95^{* *}$ \\
\hline $\mathrm{T}$ dentro de $\mathrm{T}_{14}$ & 4 & $1,14^{\star \star}$ \\
\hline$T$ dentro de $T_{21}$ & 4 & $0,85^{* *}$ \\
\hline $\mathrm{T}$ dentro de $\mathrm{T}_{28}$ & 4 & $1,12^{* *}$ \\
\hline Resíduo (B) & 40 & 0,08 \\
\hline Total & 74 & \\
\hline
\end{tabular}

IV Caso SATterthWAITE: GL $\mathrm{T}$ dentro de $\mathrm{T}_{\mathrm{a}}=42$ QMR $\mathrm{T}$ dentro de $\mathrm{T}_{\mathrm{a}}=0,09$

C.V. : Residuo $A=7,93 \% ;$ Residuo $B=5,86 \%$ ** Significativo ao nivel de $1 \%$ de probabilidade $\mathrm{NS}_{\text {Não }}$ significativo. 

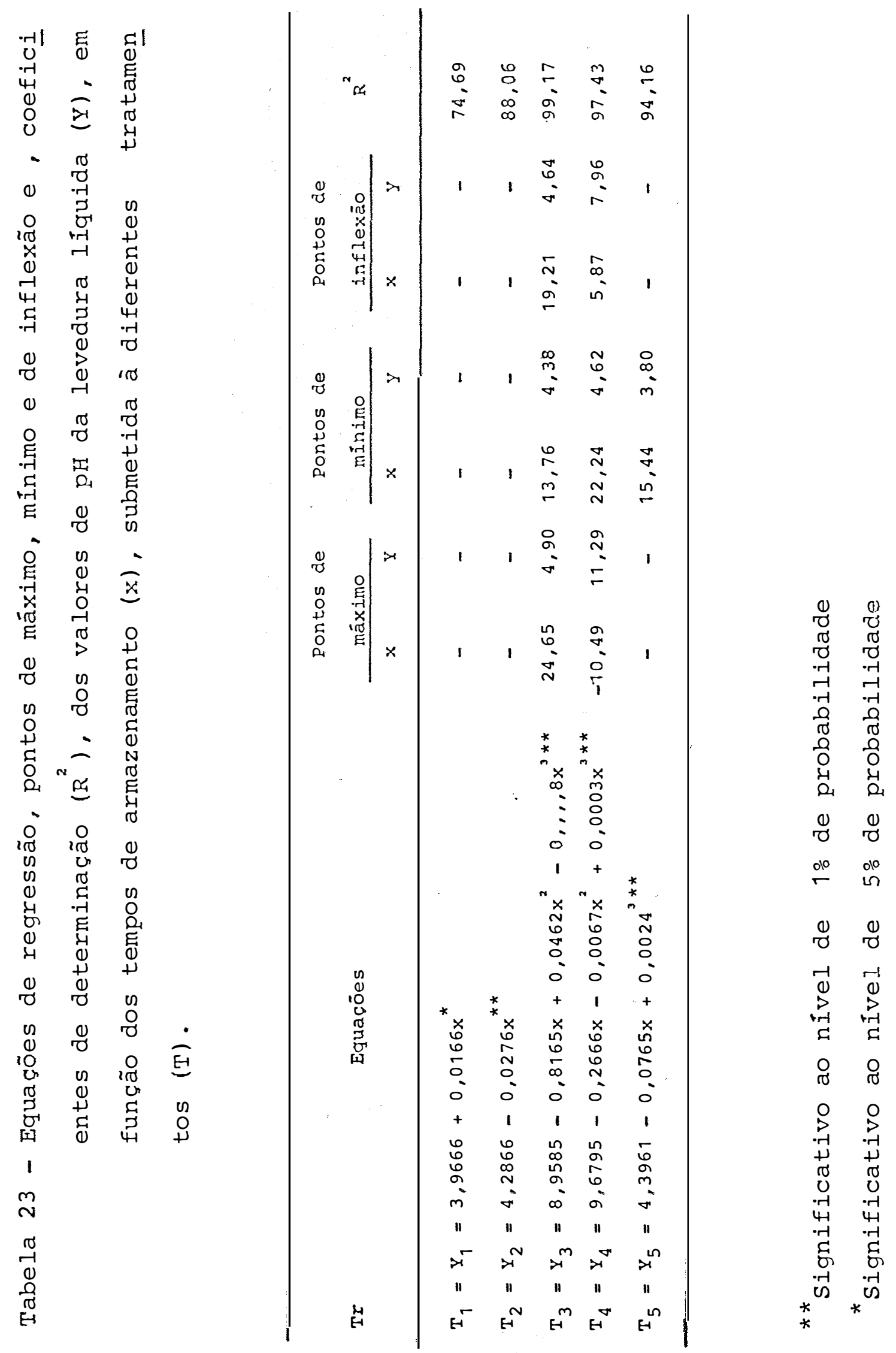


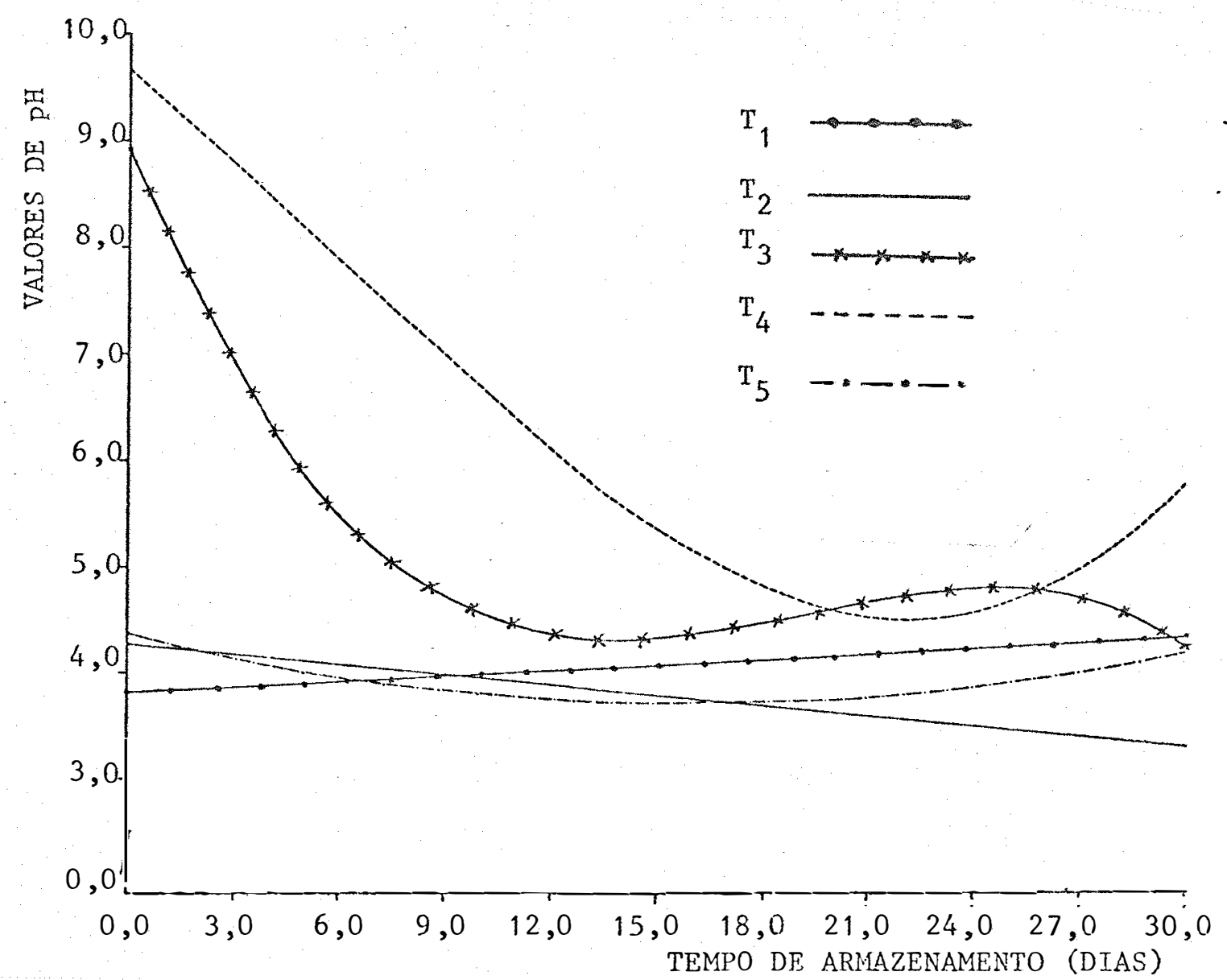

$$
\begin{array}{ll}
\mathrm{T}_{1}=\mathrm{Y}_{1}=3,9666+0,166 \mathrm{x}^{*} & \mathrm{R}^{2}=74,69 \\
\mathrm{~T}_{2}=\mathrm{Y}_{2}=4,2866-0,0276 \mathrm{x}^{* *} & \mathrm{R}^{2}=88,06 \\
\mathrm{~T}_{3}=\mathrm{Y}_{3}=8,9585-0,8165 \mathrm{x}+0,0462 \mathrm{x}^{2}-0,0008 \mathrm{x}^{3 * *} & \mathrm{R}^{2}=99,17 \\
\mathrm{~T}_{4}=\mathrm{Y}_{4}=9,6795-0,2666 \mathrm{x}-0,0,0067 \mathrm{x}^{2}+0,0003 \mathrm{x}^{3 * *} & \mathrm{R}^{2}=97,43 \\
\mathrm{~T}_{5}=\mathrm{Y}_{5}=4,3961-0,0765 \mathrm{x}+0,0024 \mathrm{x}^{2 * *} & \mathrm{R}^{2}=94,16
\end{array}
$$

Figura 7 - Curvas, equações de regressão e coeficientes de de terminação $\left(\mathrm{R}^{2}\right)$ dos valores de $\mathrm{pH}$ da levedura (Y) em função dos tempos de armazenamento (x), submeti da à diferentes tratamentos (T) . 
Verifica-se que no tratamento testemunha o $\mathrm{pH}$ aumentou linear mente, em pequena escala. Este resultado contrasta com o de STECKLEY et alii (1979a) os quais trabalhando com lodo residu al da fabricação de cerveja à temperatura de $4,4^{\circ} \mathrm{C} ; 21,0^{\circ} \mathrm{C}$ e 30,0 C , observaram uma queda do pH nos primeiros 14 dias de armazenamento e uma elevação nos ūltimos dias, para as tempera turas mais altas. Eles atribuiram o declínio inicial ao resulta do da fermentação continua com formação de produtos finais áci dos, enquanto o aumento final foi atribuido a outros processos degradativos que ocorreram apös a atividade fermentativa ter cessado.

A queda linear do $\mathrm{pH}$ no tratamento dois, possivel mente se deve à adição de $\mathrm{CO}_{2}$, efetuada por ocasião de cada amostragem, com o fim de manter a anaerobiose. A adição de hidróxido de $\underline{\text { a }}$ mônia aos tratamentos três e quatro proporcionou um aumento de $\mathrm{pH}$, nos mesmos. Todavia, a partir do 14 \% dia de armazenamen to os valores se reduziram, aproximando-se dos outros tratamen tos, e depois elevaram-se novamente no final do experimento, ha vendo portanto um comportamento cübico para ambos. A queda in $\underline{\underline{i}}$ cial possivelmente se deve à perda de amônia por volatilização, e. o aumento no final do experimento pode ser conseqüência de al gum processo degradativo.

Quanto ao tratamento cinco, a resposta foi quadrá tica e semelhante à encontrada por STECKLEY et alii (1979a), os quais atribuíram a queda inicial à formação de produtos ácidos devido à fermentação, e oaumento no final do experimento foi de 
vido à ocorrência de algum processo degradativo.

O desdobramento dos graus de liberdade, tratamen to dentro de tempo de armazenamento apresenta efeitos significa tivos $(\mathrm{P}<0,01)$ em todos os tempos de armazenamento (Tabela 22). Pelo Teste de Tukey ao nível de 5\% de probabi lidade (Tabela 21), verifica-se que os tratamentos três e qua tro tiveram os maiores valores de pH no tempo zero de armaze namento. Esta superioridade provavelmente se deve à adição de hidróxido de amônio. Os demais tratamentos apresentaram valores estatisticamente iguais.

Com sete dias de armazenamento o tratamento qua tro foi o que apresentou maior $\mathrm{pH}$, diferindo $(\mathrm{P}<0,05)$ de todos os outros tratamentos. Numa posição intermediária se situou o tratamento três e por último os tratamentos um, dois e cinco, os quais não dife riram entre si. Aos 14 dias de armazenamento os tratamentos três e quatro apresentaram os maiores valores de $\mathrm{pH}$ e os tratamentos dois e cinco os menores, ficando o tratamento um em posição intermediária.

$$
\text { Quando transcorridos } 21 \text { dias de armazenamento, }
$$

os tratamentos três e quatro apresentaram os maiores valores de $\mathrm{pH}$, os quais não diferiram do tratamento um (testemunha), que foi estatisticamente igual aos tratamentos dois e cinco.Já aos 28 dias de armazenamento, os tratamentos três e quatro apresen taram os maiores valores de $\mathrm{pH}$, sendo que o tratamento três foi semelhante aos tratamentos um e cinco, sendo este último igual ao tratamento dois que apresentou o menor valor de $\mathrm{pH}$. 


\section{CONCLUSOES}

o teor de matéria seca da levedura líquida teve um ligeiro acréscimo, durante os 28 dias de armazenamento, exce to o tratamento dois.

No tratamento testemunha, os teores de nitrogê nio solúvel, amoniacal e não protéico, elevaram-se com o pas sar do tempo, indicando degradação protéica da levedura.

A condição de anaerobiose não influenciou a con servação da levedura.

A adição de $0,3 \%$ e $0,6 \%$ de amônia aos tratamen tos três e quatro, respectivamente, proporcionou elevações nos seus teorcs de nitrogênio total, solúvel, amoniacal e não pro téico, que persistiram durante todo o tempo experimental.

A aplicação de vapor exclusiva foi suficiente para conservar a levedura liquida por 30 dias de armazenamento, em bora a aplicação conjunta de vapor e amônia e, vapor e anaero biose também tenham sido eficientes. 


\section{LITERATURA CITADA}

AMORIM, H.V. e W.R.S. HATTOS (1982) Novas Matérias Primas. Os subprodutos da Agroindústria. O Próalcool e a Produção de Levedura e Vinhaça. Perspectivas do momento. In: CONGRESSO BRASILEIRO DA INDÚSTRIA DE RAÇÕES, 1, São Paulo - SP. Anais...são Paulo, p.191-203.

BAILEY,J.L. 1967. Techniques in protein chemistry. $2^{\text {nd }}$ ed. Elsevier Publiching Company, Amsterdan, 346p.

BECKER,M. 1961. Análisis y valoracion de piensos y forrajes Ed. Acribia, Zaragoza, España, 209p.

BEESON,W.M. e T.W. PERRY, 1952. Balancing the nutritional deficiences of roughages for beef steers. J.Anim. Sci, 11: 501-515. 
BRAUDE,R. 1942. Dried yeast as fodder for livestock. J.Inst.Brew. 39: 206-217.

BUNKER,H.J. 1968. Sources of simple cell protein: perspective and prospect. In: MATELES,R.I. e TANNENBAUM,S.R. Single-cell. protein, Massachussets, M.I.T. Pres, p.67-78.

BUTOLO,J.E. 1977. Determinação do nitrogênio não protéico. Anālise de alimentos - UNESP, roteiro de aulas prāticas (mimeografado).

CAMPOS,J. 1981. Tabelas para cálculos de rações. Universidade Federal de Viçosa, Imprensa Universitária, 2o ed. 64p.

COzZOLINO,S.M.E. 1982. Valor Nutricional ảa Biomassa de Saccharomyces cerevisiae. Estudos em gerações sucessivas de ratos. Sao Paulo, Faculdade de Ciências Farmacêuticas USF, 147p. (Tese de Doutoramento).

CROOKER,B.A.; C.J. SNIFFEN,; W.H. HOOVER E L.L.JOHNSON, 1978. Solvents for soluble nitrogen meassurements in feedstuffs. J. Dairy Sci., 61: 437-447.

DESMONTS,R. 1966. Tecnologia da Profução dos Fermentos Secos de Destilarias. Boletim Informativo da A.P.M. - Piracicaba, $\underline{8}(2): 1-11$, 
DESMONTS,R. 1968. Utilização do levedo na alimentação da criança. Pediatria prática, 39(7): 7-18.

ENSMINGER,M.E. 1970. Swine Science 4 as ed., Danville. The Interstate Printers e Publishers, Inc. 882p.

GRIEVE,D.G. 1979. Feed intake and growth of cattle fed liquic. Brewer's yeast. Can. J. Anim. Sci., 59: 89-94

HSU,W.C. 1961. Protein from Sugar on Taiwan. Sugar y Azucar. New York, 56 (7): 33-36.

JACQUOT,R. 1943, Valor nutritivo das leveduras. Sua Utilização prática para a alimentação humana. In: PAIVA,B.C., Ed. 1966. Boletim Informativo da A.P.M:. Piracicaba- $\underline{8}(1): 1-13$

JARDIM,W.R. 1976. Alimentos e Alimentação do Gado Bovino. São Paulo, Ed. Agronômica Ceres. 338p.

KIHLBERG,R. 1976. The Microbe as a Source of Food. Annual Review of Microbiology, California, 26: 427-457.

LE GENDRE,G.R.; R. TOTUSEK e W.D. GALLUP, 1957. Effect of live cell yeast on nitrogen retention and digestibility of rations by beef cattle. J.Anim.Sci. 16: 671-673. 
LIMA,O.G. de, 1966. Desenvolvimento da Indústria da Levedura Alimentar e a Contribuição Brasileira. Brasil Açucareiro, 87: $24-45$

MACHADO,P.F. 1983. Valor nutritivo da levedura, residuo da produção de álcool, para vacas em lactação. Piracicaba," ESALQ-USP, 67p. (Tese de Doutoramento).

MARTELLI,H.L. 1962. Leveduras. In: ALMEIDA,J.R.; 1962 . Fermentação do caldo de cana, curso sobre fermentação alcoólica. 1ạ ed. Instituto Zimotécnico, Piracicaba, USP 1: $104-161$

MIYADA,V.S. 1978. Uso da Levedura Seca (Saccharomyces cerevisiae) de Destilaria de Álcool da Cana-de-Açucar na alimentação de Suínos em Crescimento e Acabamento. Piracicaba, ESALQ-USP, 106p. (Tese de Mestrado).

NAMORY,M. 1975. Conservation de crème de levure pour l'alimentation animale. Ann. Techbol. Agri., 24(1): 35-45.

NOGUEIRA,S.L.C. 1982, Produção e demanda de álcool no período 82/83 a 85/86. Saccharum 23: 29.32. 
PEIXOTO,A.M. e W.R.S. MATTOS. 1972. Observações sobre o valor Alimentar do Lodo Residual das Dornas de Fermentação Alcoólica em Usinas de Açucar. O Solo. Piracicaba, 64: 33-39.

PEPPLER,H.J. 1970. Food Yeasts. In: ROSE,A.H. e J.S.HARRISON. The yeasts. Academic Press. London and New York. p.421-457.

PETRAITIS,I. W S. BARANAUSKAS. 1971. Effect of liquid brewer's yeast on milk yield and mil quality. Dairy Sci. Abstr., 34: 1844 .

RAFF,W. 1967. Essais de laboratoire sur la conservation des levures de viu et de biére por voie chinique. Przem. Ferment. Rolny, $11(6): 214-217$.

SALES,A.; •; T.J.B. MENEZES; M. OKADA, T. ARAKAKI e P.R. LAMO. 1977. Produção em melaço. Coletânea do Instituto de Tecnologia de Alimentos. Campinas, 8: 443-455.

SHACKLADY, C.A. e T. WALKER. 1973. Leveduras cultivadas sobre alcanos, seguridade, empleo y utilizacion in alimentacion animal. Zootechinia, Madrid, 22 (1-2): 31-42. 
STECKLEY,J.D.; D.G. GRIEVE, G.K. MaCLEOD e E.T. MORAN JR. 1979 a. Brewer's yeast shurry. I Composition as Affected by Lenght of Storage, Temperature and Chemical Treatment. J. Dairy Sci. $62(6): 941-946$

STECKLEY,J.D.; D.G. GRIEVE; G.K. MaCLEOD e E.T. MORAN JR.m 1979 b. Brewer's yeast shurruy. II. A source of supplementary protein for lactating dairy cattle. J. Dairy Sci., 62 (6): 947953.

STREETER,C.I.; G.W. HORNe J.E. MCCLUNG, 1980. Adding yeast to mineral blocks increased intake. Feedstuffs, 52(53): 11 .

STYCZNSKI,H. 1966. Effect of feeding live yeast on rumen volatile fatty acid levels and milk fat content in cows. Dairy Sci. Abstr., 31: 2292.

TEBGE,S.B. E D.R. ZIMMERMAN, 1977. Evaluation of a yeast single-cell protein in pigs diets. J. of. Animal Sci, $45(6)$ $1309-1315$

TOMLINSON,J.E.; W.H.MCGEE e J.W. FUQUAY. 1977. Brewers condensed solubles and liquid brewers yeast as feedstuffs for lacting dairy cows. Dairy Sci. Abstr., 39: 6170 
VANANUVAT, P. 1977. Value of yeast Protein for Poultry Feeds. Critical Reviews in Food Science an Nutrition, 9: 325-343. 


\section{APÊNDICES}




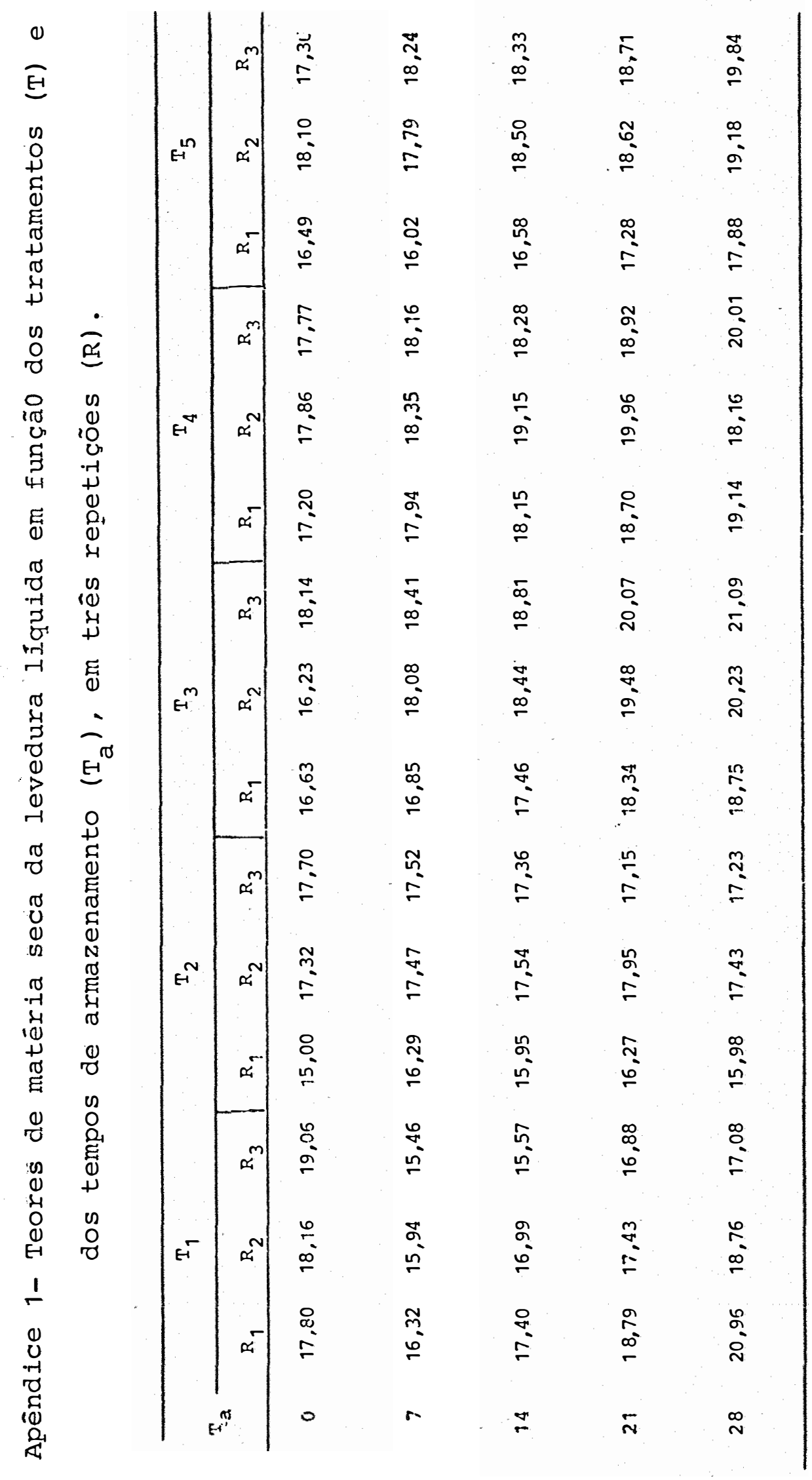




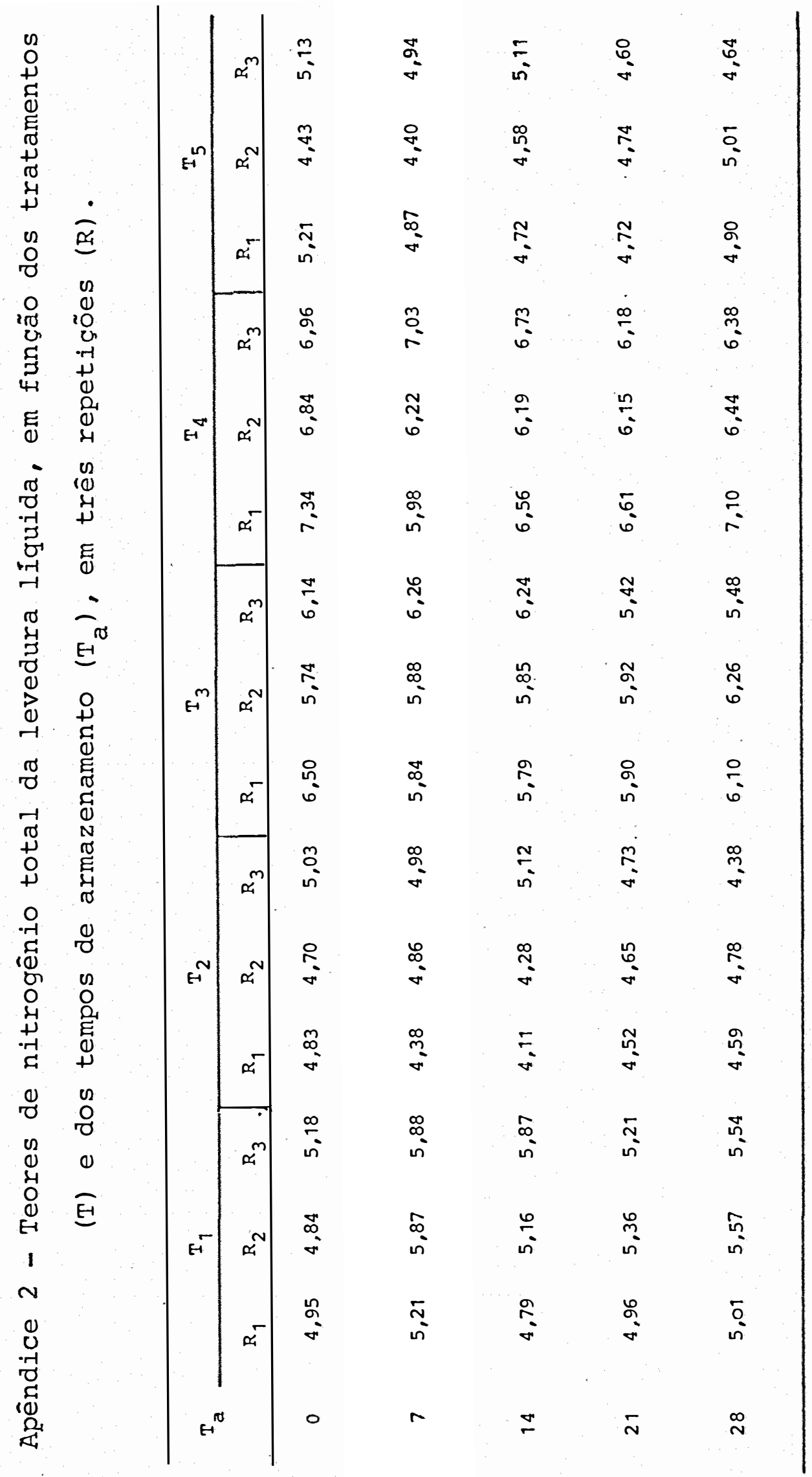




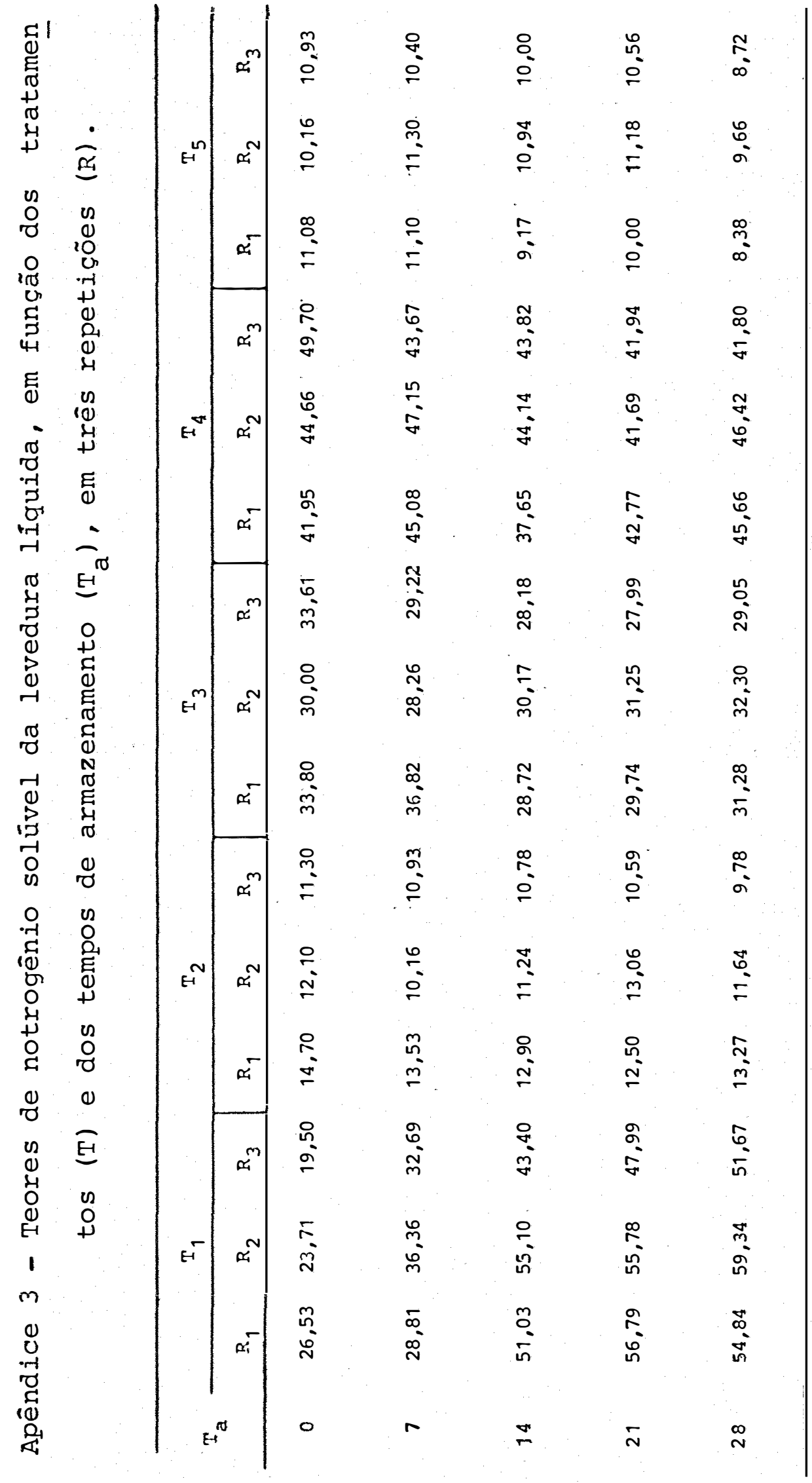




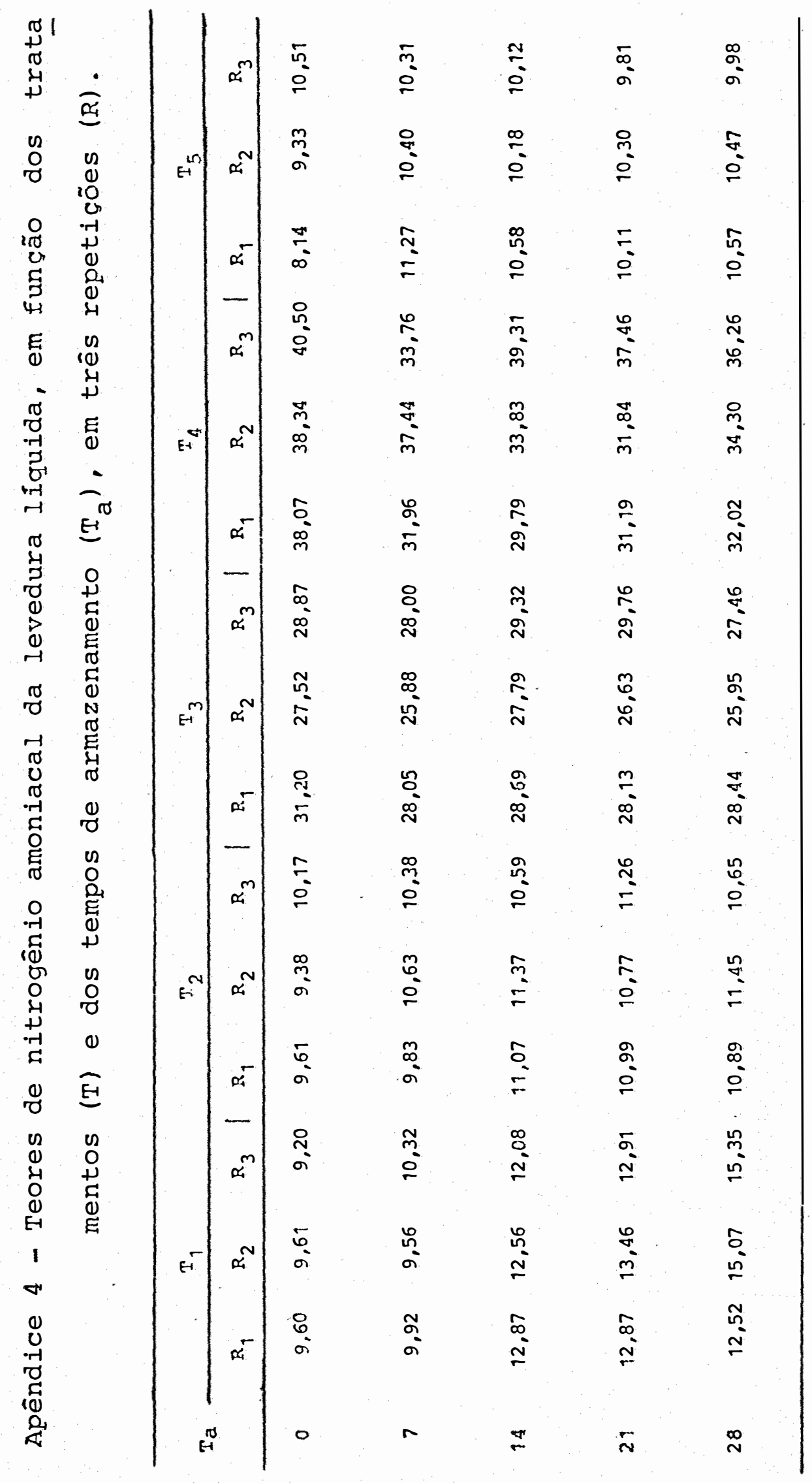




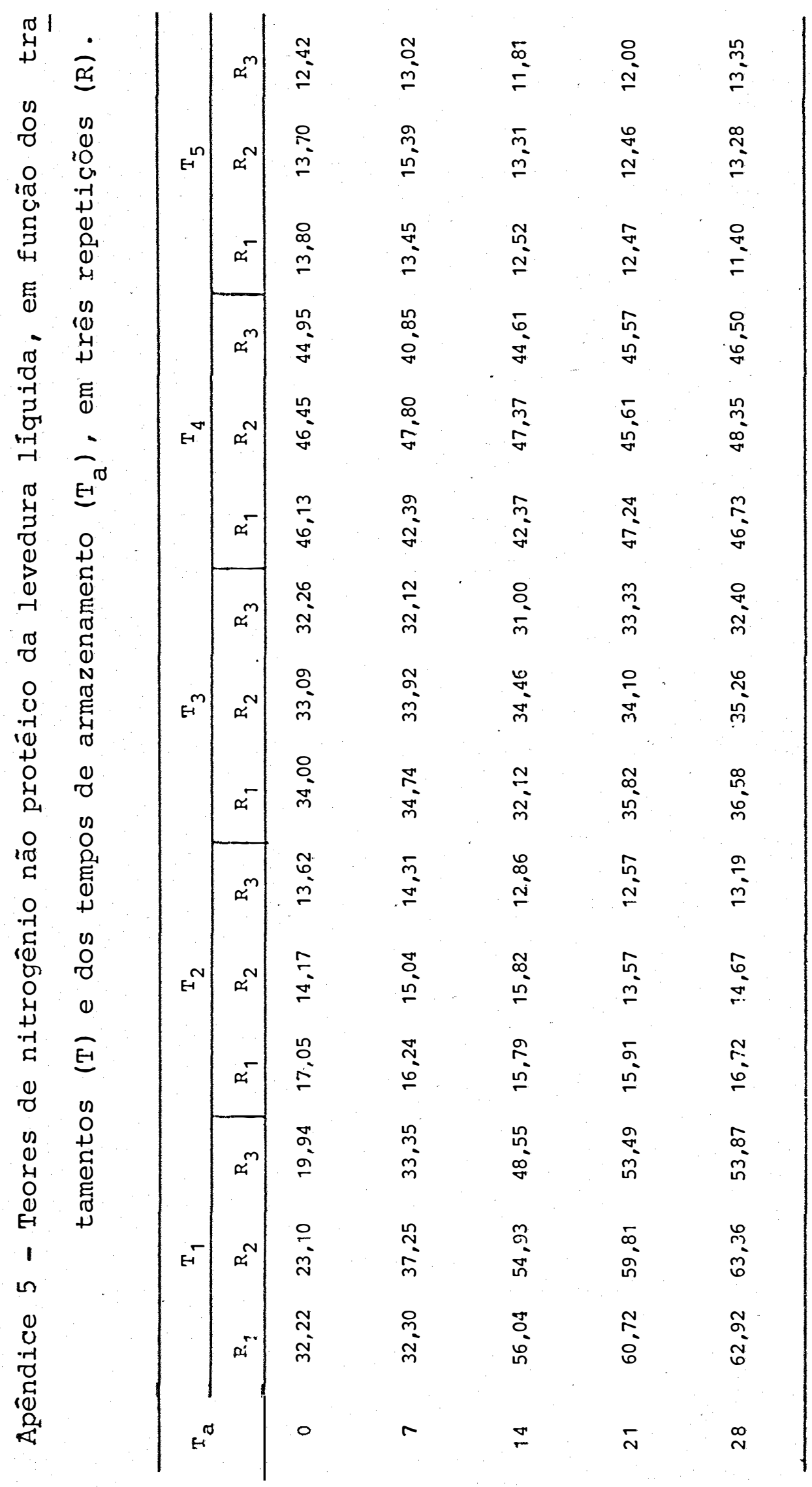




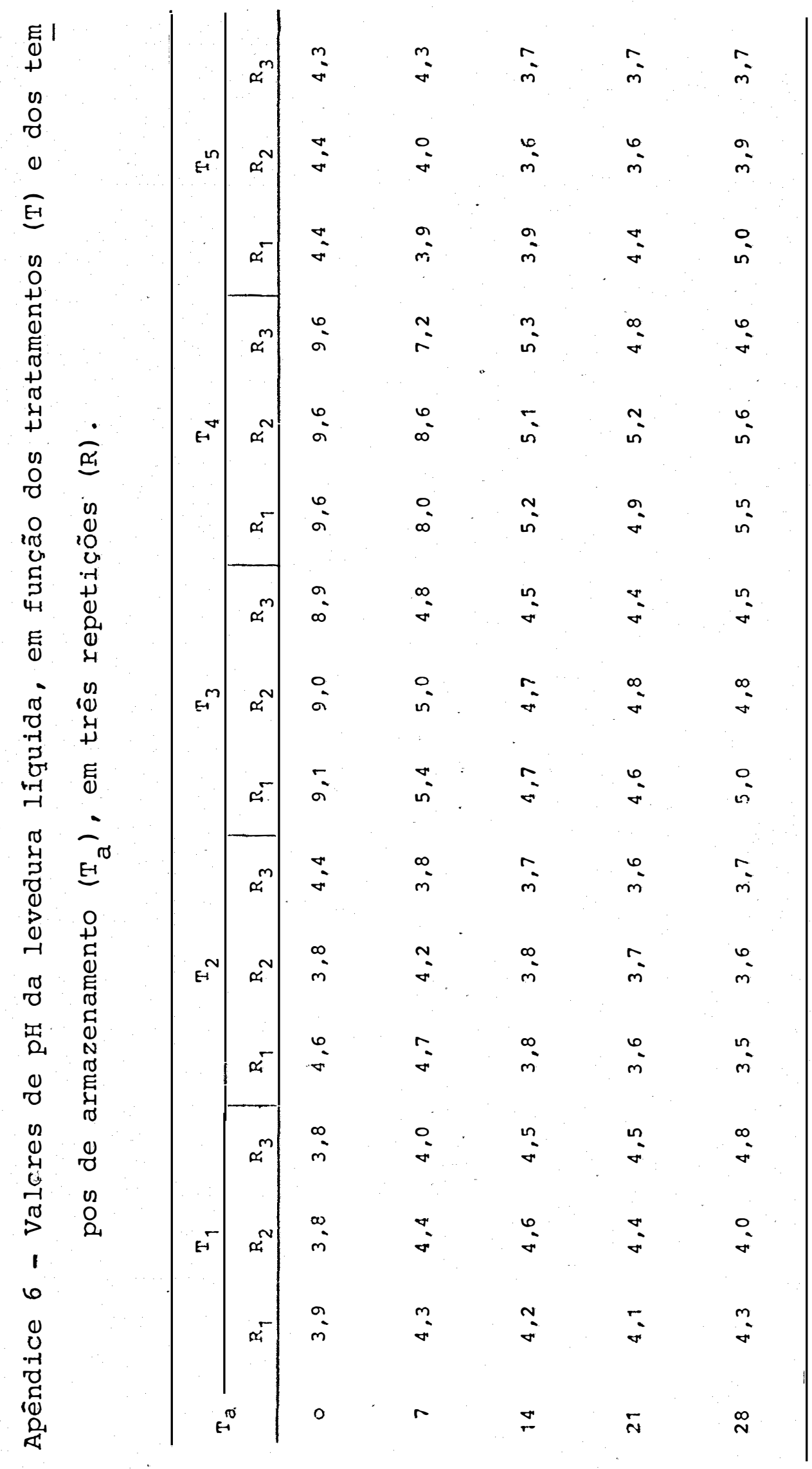

